\title{
Note
}

\section{Due Process of War in the Age of Drones}

\section{Joshua Andresen ${ }^{\dagger}$}

INTRODUCTION

I. EX ANTE JUDICIAL APPROVAL IS INADEQUATE, UNWORKABLE, AND UNCONSTITUTIONAL ....... 158

II. THE CONSTITUTIONAL DEMAND FOR JUDiCIAL REVIEW OF MiLITARY FORCE ......................... 160

III. Federal Courts ARe Competent To Review Drone Strikes ......................................... 162

A. History Demonstrates Federal Court Competence in Reviewing Military Activity ....... 164

B. Political Question Doctrine Does Not Bar Judicial Review of Military Activity........... 167

IV. REACHING THE MERITS OF DRONE STRIKES..................................................................... 170

A. The Law of War Is the Correct Law To Apply to Drone Strikes .................................. 170

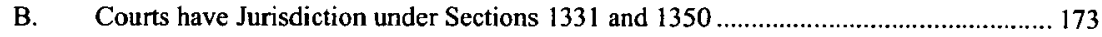

C. Violations of Distinction and Proportionality Provide a Cause of Action..................... 173

D. Victims of Drone Strikes Have Standing .............................................................. 179

E. Declaratory Relief Circumvents Sovereign Immunity ............................................. 179

F. State Secrets Are Not Jeopardized by Judicial Review ............................................... 181

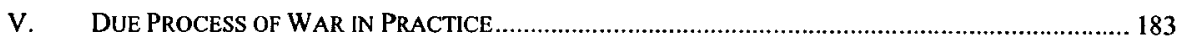

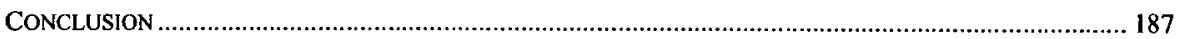

\footnotetext{
$\dagger \quad$ Robina Human Rights Fellow, Yale Law School. Yale Law School, J.D., 2015. I am indebted to Oona Hathaway and Harold Koh for their support of this project and for their constructive and insightful feedback. I am also grateful to Bruce Ackerman, Ahsan Barkatullah, Jane Chong, Samia El Osta, Gene Fidell, Owen Fiss, Robert Harrison, Paul Joo, Ryan Liss, Robert Nightingale, Daniel Nolan, Britta Redwood, Marissa Roy, William Smiley, and Raymond Mitch Verboncoeur for many helpful comments and suggestions.
} 
A wedding caravan sets out across the high desert of Yemen following the centuries old tradition of traveling to the bride's village for the wedding celebration. Shortly into the voyage the joyous procession comes to a horrific end. The procession is struck by hellfire missiles from drones commanded by the CIA, killing seventeen people, including twelve civilians and five suspected militants. ${ }^{\prime}$

Having just celebrated his sixteenth birthday, American citizen Abdulrahman Al-Aulaqi, leaves his family home in Yemen to look for his father in hiding. Accompanied by his seventeen-year-old cousin, Abdulrahman searches in vain for a month in the remote Shabwa province. Two weeks after his father had been killed, Abdulrahman, his cousin, and ten other people are killed by drone strikes at an outdoor café in a desert village. The intended target of the strike, a suspected Al Qaeda operative, was not there. A dozen people, including an American citizen and at least two minors are killed based on faulty intelligence. ${ }^{2}$

\section{INTRODUCTION}

The recent killing of one American and one Italian hostage by a U.S. drone strike has reignited the debate over how to properly rein in the errors and abuses of the drone program. ${ }^{3}$ The debate remains stalled, however, between two ineffective and constitutionally problematic extremes. At one end of the spectrum, several commentators have called for a special ex ante "drone court" tasked with approving strikes before they are carried out. ${ }^{4}$ At the other end are those who place drone strikes effectively beyond judicial review by encouraging only internal executive branch procedures. ${ }^{5}$ This Note stakes out

1. Zaid Ali \& Laura King, U.S. Drone Strike on Yemen Wedding Party Kills 17, L.A. TIMES (Dec. 13, 2013), http://articles.latimes.com/2013/dec/13/world/la-fg-wn-yemen-drone-strike-wedding $-20131213$.

2. Mark Mazzetti, Charlie Savage \& Scott Shane, How a U.S. Citizen Came To Be in America's Cross Hairs, N.Y. TIMEs (Mar. 9, 2013), http://www.nytimes.com/2013/03/10/world/middle east/anwar-al-awlaki-a-us-citizen-in-americas-cross-hairs.html.

3. Room for Debate: Should a Court Approve All Drone Strikes?, N.Y. TIMES (Apr. 24, 2015), http:/www.nytimes.com/roomfordebate/2015/04/24/should-a-court-approve-all-drone-strikes.

4. Jeh Johnson and Alberto Gonzalez have discussed this view. See Jeh Johnson, Former Gen. Counsel, Dep't of Def., Keynote Address at the Center on National Security at Fordham Law School: A 'Drone Court': Some Pros and Cons (Mar. 18, 2013); Alberto R. Gonzales, Drones: The Power To Kill, 82 GEO. WASH. L. REv. 1, 52 (2013). Senators Diane Feinstein and Angus King have also gone on record discussing the possibility of an ex ante drone court, although Senator King would restrict the usage of the court to authorizing strikes against American citizens. See Scott Shane, Debating a Court To Vet Drone Strikes, N.Y. TIMES (Feb. 8, 2013), http://www.nytimes.com/2013/02 /09/world/a-court-to-vet-kill-lists.html; see also Jeffrey S. Brand \& Amos N. Guiora, Op-Ed., Judicial Review of Planned Drone Attacks Would Save Lives, N.Y. TIMES (Apr. 24, 2015), http://www.nytimes .com/roomfordebate/2015/04/24/should-a-court-approve-all-drone -strikes/judicial-review-of-planned-drone-attacks-would-save-lives.

5. Jeh Johnson endorses this view. See Johnson, supra note 4 ("[T]he President can and should institutionalize his own process, internal to the Executive Branch, to ensure the quality of the decision-making."); $c f$. Nomination of John O. Brennan To Be Director of Cent. Intelligence Agency: Hearing Before the Select Comm. on Intelligence of the U.S. S., 113th Cong. 33 (2013) (statement of John O. Brennan, Homeland Security Advisor) ("[There is] effort [within the Executive Branch] to try to institutionalize and to ensure we have as rigorous a process as possible[, and] we feel that we're taking 
the middle ground between the extremes and argues that ex post judicial review by Article III courts is the most effective constitutional check on the drone program. Ex post judicial review is the best solution because it avoids the constitutional and national security problems presented by an ex ante drone court, while satisfying the separation of powers and remedial requirements sorely lacking when the executive remains unchecked by the judiciary.

Although ex post judicial review is the superior constitutional choice, it has been neglected due to the difficulties of explaining how judicial review of drone strikes would actually work. As the two drones cases heard in Article III courts have demonstrated, ${ }^{6}$ a plaintiff seeking to challenge the legality of a drone strike can expect to face a host of justiciability and procedural hurdles from standing to political question doctrine and sovereign immunity. Moreover, courts themselves appear to be flummoxed by the question of what law governs drone strikes and how they should apply it. This Note remedies each of these difficulties by laying out a litigation strategy for plaintiffs and a legal procedure for judges. I show that the law judges should apply to drone strikes is the same international law of war that our judge advocates (JAGs) apply to every strike carried out by the military. I also show that courts have jurisdiction to review drone strikes even under the restrictive Alien Tort Statute requirements recently narrowed by the Supreme Court in Sosa v. Alvarez-Machain ${ }^{7}$ and Kiobel v. Royal Dutch Petroleum Co. ${ }^{8}$ Finally, I show that while damages relief will not be available without an act of Congress, ${ }^{9}$ plaintiffs can win declaratory relief for strikes found to violate the law of war under the law that now exists.

The Note's argument proceeds in five parts. Part I explains why an ex ante drone court should be rejected on constitutional, national security, and practical grounds. Requiring judicial approval for military strikes would directly interfere with the President's power as Commander-in-Chief and could jeopardize national security by delaying defensive measures. The practical requirements of determining the legality of drone strikes also make an ex ante drone court unworkable. The law of war requires real-time legal determinations that could not be made in advance by a court.

Part II shows that, despite the recent trend toward executive unilateralism, our constitutional separation of powers firmly supports ex post judicial review of drone strikes. The present system of internal executive branch procedures and limited congressional reporting leaves the executive virtually unchecked. This governmental imbalance is out of touch with our constitutional values and the architecture envisioned by our Founders. I argue that ex post judicial review of drone strikes is the best way to restore our constitutional balance of powers.

Part III confronts the charges that Article III courts are not competent to

the appropriate actions at the appropriate time.").

6. Al-Aulaqi v. Panetta (Al-Aulaqi II), 35 F. Supp. 3d 56 (D.D.C. 2014); Al-Aulaqi v. Obama (Al-Aulaqi I) 727 F. Supp. 2d 1 (D.D.C. 2010).

7. 542 U.S. $692(2004)$.

8. 133 S. Ct. 1659 (2013).

9. Cf. Steve Vladeck, Why a "Drone Court" Won't Work-But (Nominal) Damages Might ..., LAWFARE (Feb. 10, 2013, 5:12 PM), https://www.lawfareblog.com/why-drone-court-wont-work -nominal-damages-might. 
review military action and that, even if our courts were competent, they would be barred by the political question doctrine from reviewing a case. ${ }^{10} \mathrm{I}$ show that federal courts have for more than two centuries applied the international law of war to uses of military force without interfering with executive prerogatives or ruling on political questions. Like the due process requirements in the Fifth and Fourteenth Amendments, the law of war defines the requirements of legal deprivations of life and property in war. I show that the international law of war is federal law under which our courts should adjudicate the lawfulness of drone strikes. ${ }^{11}$

Part IV turns to the challenge of demonstrating how plaintiffs can run the gauntlet of procedural and justiciability challenges to win a merits review of drone strikes. I lay out a litigation strategy showing that, despite the recent holdings in Sosa and Kiobel and the barrier of sovereign immunity, courts should reach the merits of an action for declaratory relief brought by civilians harmed by unlawful drone strikes.

Finally, Part V shows how courts can actually review concrete cases. I show in detail how judges can review drone strikes for their compliance with the central law of war requirements of distinction and proportionality. ${ }^{12}$ Adjudicating the legality of drone strikes by determining the military commander's compliance with the laws of distinction and proportionality is an eminently legal task that our courts should feel compelled to carry out. Adherence to the rule of law, our constitutional separation of powers, and our national security interests all speak for ex post judicial review of drone strikes.

\section{EX ANTE JUDICIAL APPROVAL IS INADEQUATE, UNWORKABLE, AND UNCONSTITUTIONAL}

The problems posed by the use of drones by an unchecked executive have led several scholars and politicians to advocate an ex ante drone court as the proper remedy. ${ }^{13}$ At first blush, ex ante judicial approval, conceived along the lines of the newly reformed standards for the FISA Court, might seem to be an effective way of promoting compliance with the laws governing drone strikes. It would, however, inevitably suffer from a number of shortcomings, each of which point to the superiority of ex post judicial review.

10. See Johnson, supra note 4; Gonzales, supra note 4; Vladeck, supra note 9; Neal K. Katyal, Who Will Mind the Drones?, N.Y. TIMES (Feb. 21, 2013), http://www.nytimes.com/2013/02/21/opinion /an-executive-branch-drone-court.html.

11. The Paquete Habana is the locus classicus for the idea that "[i]nternational law is part of our law." 175 U.S. 677,700 (1900).

12. As $\mathbf{I}$ discuss in greater detail in Part $\mathrm{V}$ below, distinction requires that "[p]arties to the conflict shall at all times distinguish between the civilian population and combatants and between civilian objects and military objectives and accordingly shall direct their operations only against military objectives." Protocol Additional to the Geneva Conventions of 12 August 1949, and Relating to the Protection of Victims of International Armed Conflicts (Protocol I) art. 48, opened for signature June 8, 1977, 1125 U.N.T.S. 3 [hereinafter Additional Protocol I]. The rule of proportionality in attack prohibits attacks "which may be expected to cause incidental loss of civilian life, injury to civilians, damage to civilian objects, or a combination thereof, which would be excessive in relation to the concrete and direct military advantage anticipated." Id. arts. 51(4), 51(5)(b).

13. See sources cited supra note 4 . 
First, while ex post judicial review would not interfere with the President's powers as Commander-in-Chief, requiring ex ante approval of drone strikes would be an unconstitutional interference with the President's duty to defend the nation. ${ }^{14}$ As a result, national security might be jeopardized if the President were forced to wait for judicial approval before ordering a defensive strike against an imminent threat.

Second, as Justice Kennedy argued in Boumediene with respect to Combat Status Review Tribunals, the closed and accusatorial nature of ex ante proceedings would be inadequate to ensure against error and vindicate the due process rights of those targeted. ${ }^{15}$ When targeting errors occur, only ex post, open, and adversarial judicial review would be adequate to vindicate victims' rights, restore the constitutional balance of powers, and reconfirm the U.S. commitment to the rule of law in military affairs.

Third, and most decisively, ex ante review of drone strikes would be incapable of adequately assessing the legality of a prospective strike. A strike that may appear to be legal now may not be legal an hour from now if, for instance, civilians have entered the target area. Judges giving ex ante approval would be forced to confront hypotheticals and give advisory opinions on a necessarily incomplete factual record. They might thus bar strikes that later circumstances make legal or approve strikes that become illegal in the circumstances in which they are carried out. ${ }^{16}$ Because the actual circumstances of a strike bear directly on its legality, the FISA Court is a poor model for review of drone strikes.

Finally, the one concern that might speak on behalf of ex ante approval, a desire to avoid second guessing battlefield decisions, simply does not apply to drone strikes. ${ }^{17}$ Unlike battlefield decisions taken under threat of enemy fire, drone strikes are cool, remote-controlled decisions vetted at multiple levels of command and far from the field of battle. ${ }^{18}$ Because the lawfulness of drone strikes is determined by the military's adherence to its own targeting rules, $e x$ post judicial review of drone strikes would be formally equivalent to a court's review of any agency's compliance with its own governing rules. By contrast,

14. See Vladeck, supra note 9 ("[I]f the Constitution protects any [presidential war powers] ..., it includes at least some discretion when it comes to . . . the President's power to use military force to defend U.S. persons and territory ...." (emphasis removed)). Vladeck also notes that an ex ante drone court would both fail the case or controversy requirement and fail to be subsumable under the warrant rationale by which the FISA Court operates. Id.

15. Boumediene v. Bush, 553 U.S. 723, 785 (2008) ("[E]ven when all the parties involved in this process act with diligence and in good faith, there is considerable risk of error in the tribunal's findings of fact. This is a risk inherent in any process that, in the words of the former Chief Judge of the Court of Appeals, is 'closed and accusatorial."').

16. See Stephen I. Vladeck, Targeted Killing and Judicial Review, 82 GEO. WASH. L. REv. ARGUENDO 11, 18 (2014) ("[W]e would never try to decide whether a law enforcement officer is legally entitled to use lethal force to protect himself or others before he actually does so. The answer, as the Supreme Court has repeatedly stressed, would depend entirely on the actual circumstances, necessarily weighed in hindsight.").

17. Throughout this Note, I refer only to strikes by Predator and Reaper drones predominately used in the targeted killing of terrorists in Pakistan, Yemen, and Somalia.

18. Drone strikes thus fall outside the bounds of 5 U.S.C. $\S 701(\mathrm{~b})(1)(\mathrm{G})$, which excepts judicial review for "military authority exercised in the field in time of war or in occupied territory." 5 U.S.C. $§ 701(b)(1)(G)(2012)$. 
an ex ante drone court would have no way of determining whether a prospective strike complied with the military's targeting rules. For constitutional, national security, and due process reasons, an ex ante drone court would only exacerbate, rather than cure, the suspicions of illegality and illegitimacy plaguing the drone program. Proposals for an ex ante drone court should be rejected as inadequate, unworkable, and unconstitutional.

\section{The CONSTITUTIONAL DEMAND FOR JUdiCIAL REVIEW OF MILITARY FORCE}

For staunch defenders of executive unilateralism, imposing a judicial check on the Commander-in-Chief may seem like a radical idea. However, judicial review of the executive's military conduct is an eminently conservative idea, integral to our constitutional separation of powers and judicial tradition. Justice Brandeis gave one of the best articulations of the purpose of separation of powers when he stated:

Checks and balances were established in order that this should be a government of
laws and not of men. . . The doctrine of the separation of powers was adopted by
the convention of 1787 not to promote efficiency but to preclude the exercise of
arbitrary power. The purpose was not to avoid friction, but, by means of the
inevitable friction incident to the distribution of the governmental powers among
three departments, to save the people from autocracy. ${ }^{19}$

Although the latter half of the twentieth century has witnessed an increase in executive war powers and unilateralism, our greater history and constitutional commitments repudiate the democratic legitimacy of an unchecked executive in foreign and military affairs. Such a conception, befitting the British monarch, was specifically rejected by the Founders and reaffirmed throughout our history. ${ }^{20}$ As John Jay wrote in the Federalist Papers, one advantage a republican union would have over monarchy is ensuring against wars "not sanctified by justice or the voice and interests of [the] people." 21 Alexander Hamilton similarly points to the distribution of war powers between the legislature and president as a check on the despotism risked by vesting complete war powers in the executive alone. ${ }^{22}$ Justice Kennedy recently underscored the paramount importance of separation of powers and judicial review of military actions in Boumediene:

Security depends upon a sophisticated intelligence apparatus and the ability of our Armed Forces to act and to interdict. There are further considerations, however. Security subsists, too, in fidelity to freedom's first principles. Chief among these are

19. Myers v. United States, 272 U.S. 52, 292-93 (1926) (Brandeis, J., dissenting) (internal quotation marks omitted); see also Youngstown Sheet \& Tube Co. v. Sawyer, 343 U.S. 579, 593 (1952) (Frankfurter, J., concurring) ("[O]n the need for limitations on the power of governors over the governed ... [the Founders] rested the structure of our central government on the system of checks and balances. For them the doctrine of separation of powers was not mere theory; it was a felt necessity.").

20. See The Federalist No. 4 (John Jay)

21. The Federalist No. 4, at 19 (John Jay) (Ian Shapiro ed., 2009).

22. See THE FEDERALIST NO. 69 (Alexander Hamilton). For an extended discussion of Hamilton's view on the limitations of Commander in Chief powers in The Federalist, see David $\mathrm{J}$. Barron \& Martin S. Lederman, The Commander in Chief at the Lowest Ebb-Framing the Problem, Doctrine, and Original Understanding, 121 HARV. L. REV. 689, 796-99 (2008). 
freedom from arbitrary and unlawful restraint and the personal liberty that is secured by adherence to the separation of powers. . . Our opinion does not undermine the Executive's powers as Commander in Chief. On the contrary, the exercise of those powers is vindicated, not eroded, when confirmed by the Judicial Branch. Within the Constitution's separation-of-powers structure, few exercises of judicial power are as legitimate or as necessary as the responsibility to hear challenges to the authority of the Executive to imprison a person.

Justice Kennedy underscores the extent to which judicial review of executive branch military action is a fundamental component of the three branch governmental system outlined by the Constitution. As in the detention cases to which Kennedy refers, ex post judicial review of drone strikes will not undermine the executive's power. Rather, judicial review has the power to vindicate the President's power by demonstrating the lawfulness of the drone program while restoring our constitutional balance of powers.

Admittedly, the balance of powers envisioned by the Founders and reconfirmed by Justice Kennedy has partially broken down. Our history has demonstrated that when separation of powers breaks down, the executive tends to acquire power at the expense of the other branches. ${ }^{24}$ With respect to military affairs in particular, Professors Barron and Lederman argue that "aggressive claims to executive power left unchallenged have a history of begetting further and more aggressive claims." ${ }^{, 25}$ Unfortunately, it is all too easy to recall what can happen when the executive branch proceeds unchecked in foreign and military affairs. The last decade alone has seen the executive employ torture, secret prisons, extraordinary rendition, warrantless wiretapping, and secret drone strikes. ${ }^{26}$ With respect to drone strikes, news reports suggest that some strikes may be carried out in violation of the most basic laws of war requiring distinction between military and civilian objects, targeting of military objects only, and the exercise of proportionality and precaution in attack. ${ }^{27}$ Rather than vindicating these strikes by demonstrating their compliance with the law of war, the government has sought to maintain a shroud of secrecy and deny the judiciary its proper power of review. ${ }^{28}$

As we transition from an active war footing to a permanent counterterrorism position, effectively reining in the secrecy and excesses of the executive by ensuring compliance with the rule of law should be a constitutional priority. ${ }^{29}$ As Professor Harold Hongju Koh convincingly

23. Boumediene, 553 U.S. at 797.

24. Cf. Bruce Ackerman \& David Golove, Is NAFTA Constitutional?, 108 HARV. L. REv. 799, 873 (1995) (discussing "piecemeal precedentialism").

25. Barron \& Lederman, supra note 22, at 712.

26. See, e.g., El-Masri v. United States, 479 F.3d 296 (4th Cir. 2007); Arar v. Ashcroft, 585 F.3d 559, 563 (2d Cir. 2009); Jewel v. Nat'l Sec. Agency, 673 F.3d 902 (9th Cir. 2011); Vance v. Rumsfeld, 701 F.3d 193, 195 (7th Cir. 2012), cert. denied, 133 S. Ct. 2796 (2013); Al-Aulaqi II, 35 F. Supp. 3d 56 (D.D.C. 2014).

27. See, e.g., supra notes 1 and 3 and accompanying text.

28. See Al-Aulaqi II, 35 F. Supp. 3d 56; Al-Aulaqi I, 727 F. Supp. $2 d 1$ (D.D.C. 2010); see also Benjamin Weiser, U.S. Ordered To Release Memo in Awlaki Killing, N.Y. TIMES (Apr. 21, 2014), http:// www.nytimes.com/2014/04/22/nyregion/panel-orders-release-of-document-in-targeted-killing-of -anwar-al-awlaki.html (describing Al-Aulaqi II).

29. See Mark Landler, U.S. Troops To Leave Afghanistan by End of 2016, N.Y. TIMES (May 
argues:

$[\mathrm{H}]$ owever different foreign affairs might be from domestic affairs, that difference does not exempt them from our constitutional system of checks and balances, particularly the check of judicial review. If anything, meaningful judicial review is even more constitutionally necessary in foreign affairs than in domestic affairs. ${ }^{30}$

Ex post judicial review of drone strikes is the best way to restore our constitutional balance of powers by requiring the executive to demonstrate its compliance with the rule of law when it kills in our name.

Ensuring that our government acts lawfully when it kills in our name not only affirms our constitutional commitments, it also buttresses our reputation at home and abroad, secures the cooperation of our allies, and keeps Americans safer. Both the executive and the military should look upon ex post judicial review as an opportunity to dispel the suspicions of illegitimacy and illegality that surround drone strikes and threaten our national security. Suspicions of unlawfulness have already jeopardized intelligence sharing abroad as several European officials face judicial review for their involvement with U.S. drone strikes. ${ }^{31}$ The withdrawal of intelligence cooperation and mounting civilian casualties make the U.S. less safe by exposing us to more terrorist threats while we lose the public relations battle at home and abroad. ${ }^{32}$ Rather than leaving the fate of the U.S. drone program to foreign and international courts, the U.S. should welcome the opportunity to get out in front of the controversy over drone strikes by demonstrating their compliance with the laws of war at home in the United States. Our constitutional commitment to separation of powers, the vindication of the drone program, and our national security all speak for $e x$ post judicial review of drone strikes.

\section{Federal Courts Are Competent To Review Drone Strikes}

Despite the long history of U.S. courts reviewing the legality of military force, the competency question has continued to plague suggestions that judges should rule on the factual and legal questions arising in the context of drone

27, 2014), http://www.nytimes.com/2014/05/28/world/asia/us-to-complete-afghan-pullout-by-end-of -2016-obama-to-say.html ("Obama said the withdrawal of combat troops from Afghanistan would free up resources to confront an emerging terrorist threat stretching from the Middle East to Africa.").

30. HaRold hongJu KoH, The National SECURity CONSTITUTION 223 (1990).

31. See Ravi Somaiya, Drone Strike Prompts Suits, Raising Fears for U.S. Allies, N.Y. TIMES (Jan. 30, 2013), http://www.nytimes.com/2013/01/31/world/drone-strike-lawsuit-raises-concerns-on -intelligence-sharing.html; Holger Stark, Drone Killing Debate: Germany Limits Information Exchange with US Intelligence, SPIEGEL ONLINE INT'L (May 17, 2011), http://www.spiegel.de/international /germany/drone-killing-debate-germany-limits-information-exchange-with-us-intelligence-a -762873.html; see also Shaheed Fatima, Noor Khan: A Missed Opportunity?, JuST SECURITY (Jan. 30, 2014, 11:30 AM), http://justsecurity.org/6530/noor-khan-missed-opportunity; Kevin Jon Heller, The Reprieve Drone Strike Communication I-Jurisdiction, OPINIO JURIS (Feb. 24, 2014, 3:55 PM), http:// opiniojuris.org/2014/02/24/reprieve-drone-strike-communication-jurisdiction. For more extensive discussion of the negative consequences of the drone program for international cooperation, see Mara Revkin, The International Costs of Illegality in the War on Terror: How the 2001 AUMF has Alienated U.S. Allies and Empowered Enemies (June 2, 2014) (unpublished manuscript) (on file with author).

32. See Heller, supra note 31; Somaiya, supra note 31; Stark, supra note 31; see also Ibrahim Mothana, How Drones Help Al Qaeda, N.Y. TimES, June 13, 2012, at A35. 
strikes. ${ }^{33}$ In part to obviate competency concerns, the President has suggested that an "independent oversight board" (IOB) within the executive branch could be employed to check drone strikes' legal compliance. ${ }^{34}$ However, as the President himself recognized, an IOB is unlikely to improve public confidence in the legality and legitimacy of drone strikes because the IOB would not be an external check and its investigations may not be made public. ${ }^{35}$ While the obvious remedy is employing the branch of government constitutionally committed to reviewing the legality of executive action, some judges and top government officials persist in the view that "courts are institutionally illequipped to assess the nature of battlefield decisions." ${ }^{36}$ While courts are indeed ill-equipped to assess the nature of battlefield decisions, courts have long demonstrated their ability to rule on the legality of those decisions. As Justice Barak maintained in the central Israeli case reviewing targeted killing,

Judicial review does not examine the wisdom of the decision to carry out military operations. The issue addressed by judicial review is the legality of the military operations. The fact that operations are necessary from a military viewpoint does not mean that they are lawful from a legal viewpoint. Indeed, we do not replace the discretion of the military commander in so far as military considerations are concerned. That is his expertise. We examine their consequences from the viewpoint of humanitarian law. ${ }^{37}$ That is our expertise. $^{38}$

A brief review of U.S. case law shows that American judges have long demonstrated their expertise in applying the international law of armed conflict to uses of military force.

33. Vladeck, supra note 16 , at 22.

34. President Barack Obama, Remarks at the National Defense University (May 23, 2013), http://www.whitehouse.gov/the-press-office/2013/05/23/remarks-President-national-defense-university. The U.K. has adopted a similar approach by appointing an Independent Reviewer of Terrorism Legislation who is given unfettered access to classified material and who publishes annual reports on the application of anti-terrorist legislation and makes recommendations for changes. See INDEPENDENT REVIEWER OF TERRORISM LEGISLATION, https://terrorismlegislationreviewer.independent.gov.uk (last visited Oct. 29, 2015).

35. Id.

36. Johnson, supra note 4 (quoting Al-Aulaqi I, 727 F.Supp.2d 1, 45 (D.D.C. 2010)); see also DaCosta v. Laird, 471 F.2d 1146, 1155 (2d Cir. 1973) ("Judges, deficient in military knowledge, lacking vital information upon which to assess the nature of battlefield decisions, and sitting thousands of miles from the field of action, cannot reasonably or appropriately determine whether a specific military operation constitutes an 'escalation' of the war or is merely a new tactical approach within a continuing strategic plan."). Contrary to Johnson's and Judge Bates' suggestions, DaCosta v. Laird is distinguishable insofar as DaCosta did not concern the legality of a particular use of military force, but "whether a specific military operation constitutes an 'escalation' of the war or is merely a new tactical approach within a continuing strategic plan." DaCosta, 471 F.2d at 1155 . Contrary to the political or strategic question posed in DaCosta, the compliance of drone strikes with the law governing armed conflict is inherently a legal question.

37. The international law of war is commonly referred to as "International Humanitarian Law." See War and Law, INT'L COMMITTEE OF THE RED CROSS, http://www.icrc.org/eng/war-and-law.

38. HCJ 769/02 Pub. Comm. Against Torture in Isr. v. Gov't of Isr. [2006](2) IsrLR 459, 514 (Isr.) (citing HCJ 4764/04 Physicians for Human Rights v. IDF Commander in Gaza [2004] IsrLR 200, 207 (Isr.)). 


\section{A. History Demonstrates Federal Court Competence in Reviewing Military Activity}

As Judge Wilkey held for the D.C. Circuit, sitting en banc, in Ramirez de Arellano $v$. Weinberger, there is a "long line of cases that permit judicial relief for unlawful or unconstitutional action by officials of the Executive Branch of the government, including relief against unlawful actions taken in the context of foreign and military affairs." 39 The "long line of cases" shows that U.S. courts have displayed remarkable competence in applying the international law of war to determine the lawfulness of U.S. military action. From Bas v. Tingy ${ }^{40}$ and Little v. Barreme ${ }^{41}$ to Hamdan v. Rumsfeld ${ }^{42}$ and Al-Bihani v. Obama, ${ }^{43}$ the nation's highest courts have not shied from reaching the merits of the lawfulness of the U.S. military's deprivations of liberty and property in war. In addition to establishing the competence of U.S. courts to review military uses of force for their compliance with international law, the case law establishes the following four core doctrinal principles: (i) that military uses of force that are subject to legal review by Article III courts; (ii) that the international law of war governs military uses of force; (iii) that both citizens and non-citizens have standing to sue for deprivations caused by U.S. military action; and (iv) that military commanders are liable for unlawful harm to civilians in war. For more than two centuries, these principles have formed the foundation of judicial review of U.S. military action.

Little v. Barreme laid much of the legal groundwork, demonstrating the judiciary's ability to rule on complex laws governing warfare, to distinguish congressional and executive war powers, to say when the executive or its agents have violated the laws governing use of military force, and to provide damages remedies for non-citizens who have suffered an illegal deprivation by the U.S. military in war. The Court's decision exemplified the application of the international law of war to military action to determine whether the U.S. military acted lawfully and, if not, what the remedy should be. Little concerned the seizure and subsequent prize-taking of a Danish vessel on the high seas by Captain Little of the U.S. Navy. Although acting in accord with the instructions of the President, Little contravened an Act of Congress authorizing the capture of vessels sailing to, but not from, French ports. ${ }^{44}$ Justice Marshall did not question whether a damages remedy should be paid if the executive or its agents are found to have acted unlawfully. Marshall's only hesitation was whether to indemnify Captain Little for following orders. As Marshall confessed, he "was strongly inclined to think that where, in consequence of orders from the legitimate authority, a vessel is seized with pure intention, the claim of the injured party for damages would be against that government from

39. Ramirez de Arellano v. Weinberger, 745 F.2d 1500, 1530 (D.C. Cir. 1984), vacated, 471 U.S. 1113 (1985).

40. 4 U.S. (4 Dall.) 37 (1800).

41. 6 U.S. (2 Cr.) 170 (1804).

42. 548 U.S. 557 (2006).

43. 590 F.3d 866 (D.C. Cir. 2010).

44. Little, 6 U.S. (2 Cr.) at 177-78. 
which the orders proceeded . ..."45 Nevertheless Marshall ultimately held that Captain Little was himself personally responsible for "damages to the owner of th[e] neutral vessel" because executive branch military orders that contradict an Act of Congress "cannot change the nature of the transaction, or legalize an act which without those instructions would have been a plain trespass." we may question whether personal liability for military personnel can be generalized from this case, Little continues to stand for the proposition that non-citizens who suffer an illegal deprivation by the U.S. government in war are entitled to a legal remedy. ${ }^{47}$

The Paquete Habana is another paradigm example of the Supreme Court applying international law to rule on the legality of military force used against non-citizens, concluding that a damages remedy is available to those suffering an unlawful deprivation. The Court analyzed the nature and content of international law at great length, surveying sources from England and the Continent to Russia and Japan. ${ }^{48}$ The Court also analyzed the relationship between U.S. law and international law, famously holding that "[i]nternational law is part of our law and must be ascertained and administered by the courts of justice of appropriate jurisdiction as often as questions of right depending upon it are duly presented for their determination." customary international law and took for granted that, in addition to ascertaining the established customary law of war among "civilized nations,",50 U.S. courts will apply treaty obligations and other positive law to military activity. In conclusion, the Court held that "it is the duty of this court, sitting as the highest prize court of the United States, and administering the law of nations, to declare and adjudge that the capture was unlawful . ..."51

The Prize Cases form yet another paradigm instance of a U.S. court applying international law of war to uses of military force. The central question taken up by the Supreme Court was whether "the President [had] a right to institute a blockade of ports in possession of persons in armed rebellion against

45. Id. at 179 .

46. Id.

47. Justice Marshall's initial inclination that the government, rather than individual servicemen, should be held liable for damages when a non-citizen suffers an unlawful military deprivation was vindicated by Justice Holmes in United States v. The Paquete Habana, 189 U.S. 453, 465-66 (1903) ("[A] decree [for damages] properly may be entered against the United States ... according to the rules applicable to private persons in like cases.").

48. The Paquete Habana, 175 U.S. 677, 698-700 (1900). For another example surveying international law, see Brown v. United States, where Justice Marshall cites the Dutch jurist, Cornelius van Bynkershoek, the Swiss jurist, Emer de Vattel, and the English jurist, Joseph Chitty. 12 U.S. 110 , 124-25 (1814). There, Marshall held that "[i]n expounding th[e] constitution, a construction ought not lightly to be admitted which would give to a declaration of war an effect in this country it does not possess elsewhere ...." Id. at 125. Justice Story, in dissent, also discussed international law at length, in particular Grotius, Puffendorf, and Vattel. Id. at 140 (Story, J., dissenting).

49. The Paquete Habana, 175 U.S. at 700. The proposition that international law is part of our law was recently reaffirmed. See Sosa v. Alvarez-Machain, 542 U.S. 692, $729-30$ (2004) (citing Tex. Indus., Inc. v. Radcliff Materials, Inc., 451 U.S. 630, 641 (1981); Banco Nacional de Cuba v. Sabbatino, 376 U.S. 398, 423 (1964); The Nereide, 13 U.S. (9 Cr.) 388, 423 (1815)) ("For two centuries we have affirmed that the domestic law of the United States recognizes the law of nations.").

50. The Paquete Habana, 175 U.S. at 686-712.

51. Id. at 714 . 
the Government, on the principles of international law, as known and acknowledged among civilized States." 52 The Court recognized that " $t]$ he right of prize and capture has its origin in the 'jus belli,' and is governed and adjudged under the law of nations." ${ }^{, 53}$ On the central issue of whether the North and South constituted belligerent parties in a war to which other nations could adopt an official stance of neutrality or become co-belligerents, the Court reasoned again from international law: "[i]t is not necessary that the independence of the revolted province or State be acknowledged in order to constitute it a party belligerent in a war according to the law of nations." 54

These three foundational cases have laid much of the groundwork for subsequent adjudications of the lawfulness of military activity. A litany of more recent cases demonstrates the courts' authority and competence to apply the international law of war to military activity and provide remedies for citizens and non-citizens alike. ${ }^{55}$ Since World War II, courts have further established several of the principles implicit in the early cases, including the key notion of command responsibility for law of war violations. For instance, in In re Yamashita, which concerned the prosecution of a Japanese military commander in the Philippines, the Court confronted the basic question of "whether the law of war imposes on an army commander a duty to . . . prevent [] . . acts which are violations of the law of war ...."56 The Court answered that the purpose of the law of war of "protect[ing] civilian populations ... from brutality would largely be defeated if the commander of an invading army could with impunity neglect to take reasonable measures for their protection." 57 Moreover, the Court found that "the law of war presupposes that its violation is to be avoided through the control of the operations of war by commanders who are to some extent responsible for their subordinates." ${ }^{, 58}$ Citing the Annex to Fourth Hague Convention of 1907 , the Court found that being "commanded by a person responsible for his subordinates" is a "condition which an armed force must fulfill in order to be accorded the rights of lawful belligerents." 59 These considerations led the Court to hold that a commander can be held legally

52. The Brig Amy Warwick (The Prize Cases), 67 U.S. 635, 665 (1862).

53. Id. at 666 .

54. Id. at 669

55. Laird v. Tatum, 408 U.S. 1, 15-16 (1972) ("[W]hen presented with claims of judicially cognizable injury resulting from military intrusion into the civilian sector, federal courts are fully empowered to consider claims of those asserting such injury; there is nothing in our Nation's history or in this Court's decided cases ... that can properly be seen as giving any indication that actual or threatened injury by reason of unlawful activities of the military would go unnoticed or unremedied."); Ex parte Quirin, 317 U.S. 1, 27-28 (1942) ("From the very beginning of its history this Court has recognized and applied the law of war as including that part of the law of nations which prescribes, for the conduct of war, the status, rights and duties of enemy nations as well as of enemy individuals."); Koohi v. United States, 976 F.2d 1328, 1331 (9th Cir. 1992) ("The Supreme Court has made clear that the federal courts are capable of reviewing military decisions, particularly when those decisions cause injury to civilians."); Ramirez de Arellano v. Weinberger, 745 F.2d 1500, 1543 (D.C. Cir. 1984) ("The Judiciary is fully empowered to vindicate individual rights overridden by specific, unconstitutional military actions."), vacated, 105 S. Ct. 2353 (1985).

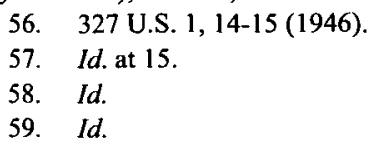


accountable for the actions of subordinates when they violate the law of war. ${ }^{60}$

The history of U.S. courts reviewing military uses of force for their compliance with international law of war demonstrates that our courts are competent to do the same with drone strikes. The case law establishes not only that the international law of war is the correct law to apply to drone strikes but that both citizens and non-citizens can sue when they are harmed by military conduct that violates the law of war. Moreover, the case law shows that military commanders are liable when civilians are unlawfully harmed in war. Contrary to what many skeptics have maintained, judicial review of drone strikes is not only possible, but a natural development of our legal history.

\section{B. Political Question Doctrine Does Not Bar Judicial Review of Military Activity}

As is well known, courts' competency in holding the military accountable to international law of war has culminated in a trio of landmark cases defining the lawful limits of military detention and adjudication. ${ }^{61}$ Yet despite the rulings in Hamdi, Hamdan, and Boumediene, courts continue to appeal to "political question doctrine" to refrain from reaching the merits of cases alleging the unlawful use of military force. ${ }^{62}$ Because political question concerns are so pervasive, explaining how the limits of political question doctrine have been misunderstood and misapplied is essential to the argument that judicial review of drone strikes can and should be embraced by the executive and the judiciary alike.

Some interpretations of the political question doctrine run the risk of implying that military conduct is wholly beyond the reach of law. ${ }^{63}$ Such an interpretation fails to identify the important middle ground between the poles set out by the D.C. Circuit: "we have distinguished between claims requiring us to decide whether taking military action was 'wise'-'a policy choice[] and value determination[] constitutionally committed for resolution to the halls of Congress or the confines of the Executive Branch'-and claims '[p]resenting purely legal issues' such as whether the government had legal authority to act." $\$ 4$ The basic question of whether military conduct was carried out in conformity to or violation of the law lies between the poles of policy choices and questions of legal authority. The question of whether a particular military

60. Id. at 16. For further discussion of In re Yamashita and command responsibility, see MICHAEL NEWTON \& LARRY MAY, PROPORTIONALITY IN INTERNATIONAL LAW 95-100 (2014).

61. See Boumediene v. Bush, 553 U.S. 723 (2008); Hamdan v. Rumsfeld, 548 U.S. 557 (2006); Hamdi v. Rumsfeld, 542 U.S. 507 (2004). On remand from Boumediene, Judge Leon of the D.C. District Court found that the "Government has failed to carry its burden" in proving that Boumediene and four others qualified as enemy combatants and thus ordered their release. Boumediene v. Bush, 579 F. Supp. 2d 191, 197 (D.D.C. 2008), rev'd sub nom. Bensayah v. Obama, 610 F.3d 718 (D.C. Cir. 2010).

62. Two recent examples are Al-Aulaqi I, 727 F. Supp. 2 d 46 (D.D.C. 2010), and El-Shifa Pharmaceutical Industries Co. v. United States, 607 F.3d 836, 844 (D.C. Cir. 2010) ("In military matters in particular, the courts lack the competence to assess the strategic decision to deploy force or to create standards to determine whether the use of force was justified or well-founded.").

63. See, e.g., Johnson, supra note 4; Vladeck, supra note 9.

64. El-Shifa, 607 F.3d at 844 (internal quotation marks removed). 
action, such as seizure of a ship or bombing of a pharmaceutical factory, was wise or good policy is indeed a "political" question improperly considered by the courts.

By contrast, the question of whether the seizure or bombing was lawful belongs to the most essential function of the courts. Moreover, the legality of a particular military action is not exhausted in answering the question of whether the action was undertaken with proper legal authority. The more basic question is whether the action was carried out in a lawful manner. For example, police officers with a search warrant may have the legal authority to search a house. However, it is another legal question altogether whether, in conducting the lawfully authorized search, the police conducted themselves in a lawful manner. Even when authorized to search a house, the police are not licensed to do so in any manner they see fit. ${ }^{65}$ They cannot recklessly endanger the inhabitants of the home, for instance. Similarly, when the nation is at war the military is authorized to use lethal force against the enemy. They may not, however, recklessly endanger enemy civilians. ${ }^{66}$ Holding military uses of force accountable to the law of war is not interfering in a political question nor engaging in a judicial practice for which the American judiciary lacks competence. As we have seen, U.S. courts have for more than two centuries held the U.S. military accountable to the law of war.

Koohi $v$. United States is a recent example of federal courts rejecting political question objections and reviewing U.S. military activity. On the question of the justiciability of the U.S. Navy wrongfully firing upon an Iranian civilian aircraft and killing all 290 people aboard, the Ninth Circuit found that "the fact that the plaintiffs' lawsuit involves the operation of a United States warship does not render it beyond judicial cognizance." ${ }^{67}$ The court went on to find that the lawsuit was not "judicially unmanageable because the challenged conduct took place as part of an authorized military operation. The Supreme Court has made clear that the federal courts are capable of reviewing military decisions, particularly when those decisions cause injury to civilians." 68 Although the Ninth Circuit ultimately dismissed the claim in Koohi on sovereign immunity grounds, it belongs to an important line of cases, including

65. Cf. Philadelphia Co. v. Stimson, 223 U.S. 605, 619-20 (1912) (citing Little v. Barreme, 6 U.S. (2 Cr.) 170 (1804)) ("The exemption of the United States from suit does not protect its officers from personal liability to persons whose rights of property they have wrongfully invaded."). Goltra $v$. Weeks, 271 U.S. 536, 545 (1926), quotes the passage from Philadelphia Co. in its entirety. See also Belknap v. Schild, 161 U.S. 10, 18 (1896) (citing Little, 6 U.S. (2 Cr.) 170; Bates v. Clark, 95 U.S. 204 (1877)) (" $[\mathrm{T}]$ he exemption of the United States from judicial process does not protect their officers and agents, civil or military, in time of peace, from being personally liable to an action of tort by a private person whose rights of property they have wrongfully invaded or injured, even by authority of the United States.").

66. Additional Protocol I, supra note 12, art. 48.

67. Koohi v. United States, 976 F.2d 1328, 1331 (9th Cir. 1992); see also United States v. United Cont'1 Tuna Corp., 425 U.S. 164, 181-82 (1976) (holding that a suit alleging that a naval vessel negligently collided with a merchant ship may be brought against the United States if it satisfies the reciprocity requirements of the Public Vessels Act); United Air Lines, Inc. v. Wiener, 335 F.2d 379, 392-95 (9th Cir. 1964) (allowing suit for aeronautic disaster arising from negligence during military training mission). case." Id.

68. Koohi, 976 F.2d at 1331. The court referred to The Paquete Habana as "the controlling 
Ramirez de Arellano, the detention cases, ${ }^{69}$ and the recent $A$-Aulaqi case, ${ }^{70}$ in which courts have not found political questions when asked to review military uses of force.

Of all the cases in the last decade that have been dismissed on political question grounds, ${ }^{71}$ El-Shifa Pharmaceutical Industries Co. v. United States provides the most instructive discussion of why these cases fail to reach the merits. There, Judge Griffith found that "courts cannot reconsider the wisdom of discretionary foreign policy decisions" and accordingly dismissed the case. ${ }^{72}$ As Griffith rightfully pointed out, "Whether an attack on a foreign target is justified-that is whether it is warranted or well-grounded-is a quintessential policy choice and value determination constitutionally committed for resolution to the halls of Congress or the confines of the Executive Branch."73 Griffith went on to explain that "the presence of a political question in these cases turns not on the nature of the government conduct under review but more precisely on the question the plaintiff raises about the challenged action." ${ }^{, 74}$ In El-Shifa, "the plaintiffs' law-of-nations claim falls squarely within this prohibition because it would require [the court] to declare that the bombing of the El-Shifa plant was "mistaken and not justified.", 75 Judge Griffith made perfectly explicit that the plaintiffs might have had a legitimate legal claim, but they simply failed to raise a proper legal question. Judge Griffith thus indicated that U.S. military action is perfectly open to challenge. However, in order to raise a legal challenge in court, a plaintiff cannot present the issue as a policy question or invoke only vaguely applicable law. Successfully challenging U.S. military activity depends on raising the appropriate legal questions.

In contrast to the types of claims that raise political questions, reviewing the legality of drone strikes according to the deeply entrenched laws of distinction and proportionality both gives the court substantive law to apply and asks only whether the government action in question satisfied or violated the law. The threshold question is not whether the President is justified in his decisions to defend the nation as Commander-in-Chief. Rather, the question is whether, in carrying out the drone strike, the commander of the strike satisfied the laws of distinction and proportionality. That is, the question is not whether targeting the enemy was justified, but whether the targeting was carried out in a legal manner. A military commander who fails to satisfy distinction and proportionality will have conducted an unlawful strike even if he had authority to order a strike. If military commanders are not free to abandon the law of war in conducting drone strikes, courts should reach the merits of a well-pled complaint alleging violation of the law of war.

69. See, e.g., Boumediene, 553 U.S. at 723; Hamdan, 548 U.S. at 557; Hamdi, 542 U.S. at 507.

70. Al-Aulaqi II, 35 F. Supp. 3d at 56 ("The Court concludes that the political question doctrine does not bar its review of Plaintiffs' Complaint.").

71. See El-Shifa Pharm. Indus. Co. v. United States, 559 F.3d 578, 584 (D.C. Cir. 2009), aff'd, 607 F.3d 836 (D.C. Cir. 2010) (en banc).

72. El-Shifa Pharm. Indus. Co. v. United States, 607 F.3d 836, 844 (D.C. Cir. 2010) (en banc).

73. Id. at $844-45$ (internal quotations omitted).

74. Id. at 842 (emphasis added).

75. Id. at 844 . 


\section{REACHING THE MERITS OF DRONE STRIKES}

Stepping back from the separation of powers and national security reasons for ex post judicial review of drone strikes, it is clear that any case the judiciary ultimately reviews will have to start with a well-formed complaint by a plaintiff with standing. Until now, the only actions seeking judicial review of drone strikes have been brought by American citizens seeking injunctive relief and damages for alleged constitutional violations. ${ }^{76}$ Both Al-Aulaqi cases failed to reach the merits on procedural and justiciability grounds. As the discussion of the political question doctrine demonstrates, the main failing, common to both recent drone cases, is that plaintiffs failed to identify with any precision an applicable federal law that limits the executive's actions in war and which the court could apply to determine the legality of the strike. Because the courts were not presented with clearly applicable federal law against which the executive's actions could be adjudicated, the judges found the uncertain application of the Fourth and Fifth Amendments to the executive's use of lethal military force raised political questions ${ }^{77}$ or, alternatively, that "special factors" counseled against extending a remedy in such cases. Even if the approach taken in the Al-Aulaqi cases had been successful, well-settled precedent suggests that courts would be unwilling to extend constitutional protections to non-citizens outside of U.S. territory. ${ }^{79}$ Thus, the overwhelming majority of civilians harmed by drone strikes would be unable to bring a case on the same grounds. Although we have seen that our courts have a long history of reviewing military uses of force for their compliance with the law of war, any attempt to win judicial review of drone strikes today will have to identify the correct law governing drone strikes and then overcome a host of procedural and justiciability hurdles to reach the merits. This Part shows how plaintiffs can do just that by first identifying the law actually governing drones strikes and then showing how plaintiffs can clear each hurdle from jurisdiction and cause of action to sovereign immunity and state secrets.

\section{A. The Law of War Is the Correct Law To Apply to Drone Strikes}

A successful case challenging the legality of a particular drone strike must claim a violation of a federal law that actually governs the military's use of force. While it remains unclear just how the Bill of Rights might govern military targeting, the executive and the military have long acknowledged that the law of war governs targeting. For instance, the United States Air Force Doctrine Document, Targeting, states that " $[\mathrm{t}] \mathrm{he}$ 'law of war' is a term encompassing all international law for the conduct of hostilities binding on the

76. See Al-Aulaqi II, 35 F. Supp. 3d 56 (D.D.C. 2014); Al-Aulaqi I, 727 F. Supp. 2d 1 (D.D. C. 2010).

77. Al-Aulaqi I, 727 F. Supp. 2d at 46 ("'[P]laintiff's claims pose precisely the types of complex policy questions that the D.C. Circuit has historically held non-justiciable under the political question doctrine.").

78. Al-Aulaqi II, 35 F. Supp. 3d at 66 ("[T]he motion to dismiss will be granted because special factors counsel hesitation in implying a Bivens remedy in these circumstances.").

79. United States v. Verdugo-Urquidez, 494 U.S. 259, 269 (1990). 
United States including treaties and international agreements to which the United States is a party, and applicable customary international law." ${ }^{, 80}$ The Air Force goes on to specify that "[t]argeting must adhere to the [law of war]" which "rests on four fundamental principles that are inherent to all targeting decisions," among which are "distinction" and "proportionality." Targeting defines the "Role of the Judge Advocate" to include "an affirmative duty to provide legal advice to commanders and their staffs that is consistent with the international and domestic legal obligations." 82 Military lawyers are required to make a legal evaluation of distinction and proportionality before

80. U.S. AIR FORCE, TARgeting, Air Force Doctrine Doc. 3-60, at 88 (June 8, 2006) (emphasis added).

81. Id. The other two principles are military necessity and unnecessary suffering, or "humanity." The Air Force also explains that "LOAC [Law of Armed Conflict]" and "law of war" are synonymous. Id. ("The "law of war' is also commonly referred to as the LOAC."). The law of distinction specifies that "[p]arties to the conflict shall at all times distinguish between the civilian population and combatants and between civilian objects and military objectives and accordingly shall direct their operations only against military objectives." Additional Protocol I, supra note 12, art. 48; see also id. arts. 44(3) ("In order to promote the protection of the civilian population from the effects of hostilities, combatants are obliged to distinguish themselves from the civilian population while they are engaged in an attack or in a military operation preparatory to an attack."), 48 ("In order to ensure respect for and protection of the civilian population and civilian objects, the Parties to the conflict shall at all times distinguish between the civilian population and combatants and between civilian objects and military objectives and accordingly shall direct their operations only against military objectives."), 51(3) ("Civilians shall enjoy the protection afforded by this Section, unless and for such time as they take a direct part in hostilities."), 51(5)(a) (“[A]n attack by bombardment by any methods or means which treats as a single military objective a number of clearly separated and distinct military objectives located in a city, town, village or other area containing a similar concentration of civilians or civilian objects [shall be considered as indiscriminate]."), 52(2) ("Attacks shall be limited strictly to military objectives. In so far as objects are concerned, military objectives are limited to those objects which by their nature, location, purpose or use make an effective contribution to military action and whose total or partial destruction, capture or neutralization, in the circumstances ruling at the time, offers a definite military advantage."), 57(2)(a)(ii) ("[T]hose who plan or decide upon an attack shall ... take all feasible precautions in the choice of means and methods of attack with a view to avoiding, and in any event to minimizing, incidental loss of civilian life, injury to civilians and damage to civilian objects."), and 57(3) ("When a choice is possible between several military objectives for obtaining a similar military advantage, the objective to be selected shall be that the attack on which may be expected to cause the least danger to civilian lives and to civilian objects."). The law of proportionality prohibits attacks "which may be expected to cause incidental loss of civilian life, injury to civilians, damage to civilian objects, or a combination thereof, which would be excessive in relation to the concrete and direct military advantage anticipated." Id. arts. 51(4), 51(5)(b); see also Rome Statute of the International Criminal Court art. 8(2)(b)(iv), July 17, 1998, 2187 U.N.T.S. 90 [hereinafter Rome Statute] ("[S]erious violations of the laws and customs applicable in international armed conflict, within the established framework of international law, namely, any of the following acts: Intentionally launching an attack in the knowledge that such attack will cause incidental loss of life or injury to civilians or damage to civilian objects or widespread, long-term and severe damage to the natural environment which would be clearly excessive in relation to the concrete and direct overall military advantage anticipated."); Additional Protocol I, supra note 12, arts. 57(2)(a)(ii) ("[T] hose who plan or decide upon an attack shall take all feasible precautions in the choice of means and methods of attack with a view to avoiding, and in any event to minimizing, incidental loss of civilian life, injury to civilians and damage to civilian objects."), and 57(2)(b) ("[A]n attack shall be cancelled or suspended if it becomes apparent that the objective is not a military one or is subject to special protection or that the attack may be expected to cause incidental loss of civilian life, injury to civilians, damage to civilian objects, or a combination thereof, which would be excessive in relation to the concrete and direct military advantage anticipated."). The U.S. Navy manual defines proportionality as "a balancing test to determine if the incidental injury, including death to civilians and damage to civilian objects, is excessive in relation to the concrete and direct military advantage expected to be gained." DEP'T OF THE NAVY ET AL., THE COMMANDER'S HANDBOOK ON THE LAW OF NAVAL OPERATIONS $\$ 5.3 .3$ (2007).

82. U.S. AIR FORCE, supra note 80 , at 95. 
any strike. While commanders may override the JAG's particular recommendation, commanders are still bound to adhere to the laws of distinction and proportionality for any strike they order.

What this means for judges who will review drone strikes for their compliance with the law of war is that they will have a wealth of legal analyses before them. Just as Israeli judges and judges at international tribunals have adjudicated alleged violations of distinction and proportionality, U.S. judges will adjudicate whether commanders reasonably adhere to the law. ${ }^{83}$ Where commanders have fired only on military objects and reasonably calculated military advantage to outweigh anticipated civilian casualties, the drone strike should be found lawful. Such findings will reinforce the practice of distinguishing military from civilian objects and calculating proportionality, while contributing to much needed jurisprudence on the subject in the U.S. Where, however, the requirements of distinction and proportionality have been egregiously flouted, perhaps by firing at a civilian object or failing to consider anticipated civilian casualties, the strike should be found unlawful. Such findings, and the accompanying public, international, and security repercussions, ${ }^{84}$ will serve to compel future compliance with the law of war and deter disregard for the rights and legal protections of civilians in war. As Federal courts have done throughout the last decade with respect to detention, ${ }^{85}$ those same courts can apply the law of war to drone strikes to protect fundamental rights and assure the legality and legitimacy of government activity in war. The laws of distinction and proportionality as defined in customary international law and explicitly embraced as binding on military targeting are the appropriate federal law to apply when reviewing the legality of drone strikes. ${ }^{86}$ As I will now show, an action seeking declaratory judgment

83. The reasonableness standard for compliance with the law of armed conflict is used by the International Criminal Tribunal for the Former Yugoslavia, which held in Galic that the appropriate standard for assessing compliance with proportionality in armed conflict is "whether a reasonably wellinformed person in the circumstances of the actual perpetrator, making reasonable use of the information available to him or her, could have expected excessive civilian casualties to result from the attack." Prosecutor v. Galić, Case No. IT-98-29-T, Judgement and Opinion, $\$ 58$ (Int'l Crim. Trib. for the Former Yugoslavia, Dec. 5, 2003); see also In re Yamashita, 327 U.S. 1, 15 (1946); HCJ 769/02 Pub. Comm. Against Torture v. Government [2006](2) IsrLR 459 (Isr.); Bundesgerichtshof [BGH] [Federal Court of Justice]Apr. 16, 2010, NEUE ZEITSCHRIFT FÜR STRAFRECHT [NSTZ] 581, 2010 (Ger.).

84. On the problem of decreased intelligence cooperation, and thus decreased security due to fears that drone strikes have been carried out in violation of the law of war, see Somaiya, supra note 31; Stark, supra note 31 .

85. In Hamdi v. Rumsfeld, the Court analyzes international law of war at length to support the proposition that while detention of enemy combatants is authorized for the duration of hostilities, indefinite detention is not authorized. 542 U.S. 507, 520 (2004) ("It is a clearly established principle of the law of war that detention may last no longer than active hostilities."). In Hamdan v. Rumsfeld, the Court analyzes the international law of war at length and concludes that the military commission that was to try Hamdan was unlawful because it complied neither with the international law that the U.S. had acceded to by treaty nor with customary international law that the U.S. had not ratified but nevertheless came to accept as binding. 548 U.S. 557, 631-35 (2006) ("Common Article 3 obviously tolerates a great degree of flexibility in trying individuals captured during armed conflict; its requirements are general ones .... But requirements they are nonetheless. The commission that the President has convened to try Hamdan does not meet those requirements."). For an extended discussion of U.S. courts' application of the law of war to detention cases, see Oona Hathaway et al., The Power To Detain: Detention of Terrorism Suspects After 9/11, 38 YALE J. INT'L L. 123, 153-61 (2013).

86. For the proposition that customary international law is federal law, see The Paquete 
brought by a victim of a drone strike carried out in violation of distinction or proportionality should be granted a merits review in U.S. federal court.

\section{B. Courts have Jurisdiction under Sections 1331 and 1350}

Federal Courts should recognize that they have jurisdiction to review the legality of drone strikes under 28 U.S.C. $\S 1331$ and $\S 1350$. Section 1331 grants federal district courts jurisdiction over "all civil actions arising under the Constitution, laws, or treaties of the United States." 87 As we have seen, the laws of distinction and proportionality are central elements of the law of war that the U.S. has affirmed as binding on its military operations. As legally binding customary international law, distinction and proportionality form part of our federal law and the violation of these principles raises a federal question. ${ }^{88}$ Federal district courts thus have jurisdiction to review drone strikes for their compliance with the laws of distinction and proportionality.

For all cases brought by foreign nationals, federal question jurisdiction can be complemented by the jurisdiction granted by section 1350 , commonly referred to as the Alien Tort Statute (ATS). Section 1350 grants district courts "original jurisdiction of any civil action by an alien for a tort only, committed in violation of the law of nations or a treaty of the United States." ${ }^{, 99}$ As central pillars of the law of war and ratified treaty obligations of 174 countries, 90 distinction and proportionality are core instances of the law of nations today. Federal district courts should thus find that they have jurisdiction over tort cases brought by foreign nationals harmed by unlawful drone strikes.

\section{Violations of Distinction and Proportionality Provide a Cause of Action}

Although federal question and ATS jurisdiction for judicial review of drone strikes is relatively straightforward, the holdings in Sosa and Kiobel and some judicial interpretations of the law of war make claiming a private cause of action for violations of distinction or proportionality the greatest legal challenge for plaintiffs. For cases brought solely under federal question jurisdiction, judges should find a direct cause of action for a violation of distinction or proportionality. Although some judges have argued that the law of war does not grant a private cause of action for individuals, ${ }^{91}$ as we have

Habana, 175 U.S. 677, 700 (1900). See also Harold Koh, Is International Law Really State Law?, 111 HARV. L. REV. 1824, 1839 (1998).

87. 28 U.S.C. $\S \S 1331(2012)$

88. $I d$.

89. 28 U.S.C. $\$ 1350$ (2012).

90. See Additional Protocol I, supra note 12. For a list of States Parties to Additional Protocol I, see Treaties and States Parties to Such Treaties, INT'L COMM. OF THE RED CROSS, https://www.icrc .org/applic/ihl/ihl.nsf/States.xsp?xp_viewStates=XPages_NORMStatesParties\&xp_treatySelected=470 (last visited Nov. 13, 2015). As demonstrated by the U.S. Air Force Doctrine Document, Targeting, although the U.S. is not a state party to Additional Protocol I, it nevertheless considers distinction and proportionality to be binding customary international law. U.S. AIR FORCE, supra note 80, at 88.

91. Judge Bork famously argued, on essentially political question grounds, that survivors and the estates of persons attacked on a bus in Israel had no private cause of action under the law of nations. 
seen, federal courts have consistently adjudicated individual claims against the United States for violations of the law of war. As we saw in Little, The Prize Cases, and The Paquette Habana, the Court directly applied the law of war to government action to review its legality. More recently, in Hamdan $v$. Rumsfeld, the Court adjudicated the claim that Hamdan's rights under the law of war had been violated by the improperly constituted military commission in which he was tried. ${ }^{92}$ In Al-Bihani v. Obama, the D.C. Circuit adjudicated AlBihani's claim that the international law of co-belligerency made his detention unlawful. ${ }^{93}$ Federal court adjudications of law of war claims show that they confer a cause of action on individuals harmed by unlawful military activity. As the Court found in Laird v. Tatum, "when presented with claims of judicially cognizable injury resulting from military intrusion into the civilian sector, federal courts are fully empowered to consider claims of those asserting such injury.",94

Despite the central position of distinction and proportionality in international law, any case claiming ATS jurisdiction will likely be challenged by the limitations recently imposed by the Supreme Court in Sosa v. AlvarezMachain and Kiobel v. Royal Dutch Petrole. Co. In Sosa, the Court limited the law of nations violations actionable under section 1350 to those with no "less definite content and acceptance among civilized nations than the historical paradigms familiar when $\S 1350$ was enacted." 95 In Kiobel, the Court limited the territorial reach of section 1350 to "claims [that] touch and concern the territory of the United States ... . with sufficient force to displace the presumption against extraterritorial application." in violation of the law of war satisfy the criteria set out in Sosa and Kiobel for three fundamental reasons: (i) because distinction and proportionality are universally recognized norms placing definite limitations on war; (ii) because violations committed by the U.S. military directly touch and concern the United States; and (iii) because recognizing a cause of action for such violations in

See Tel-Oren v. Libyan Arab Republic, 726 F.2d 774, 799 (D.C. Cir. 1984) ("Neither the law of nations nor any of the relevant treaties provides a cause of action that appellants may assert in courts of the United States. Furthermore, we should not, in an area such as this, infer a cause of action not explicitly given. In reaching this latter conclusion, I am guided chiefly by separation of powers principles, which caution courts to avoid potential interference with the political branches' conduct of foreign relations.").

92. 548 U.S. 557, 628 (2006) ("[R]egardless of the nature of the rights conferred on Hamdan, they are, as the Government does not dispute, part of the law of war. And compliance with the law of war is the condition upon which the authority [to convene a military commission] is granted." (internal citations omitted)).

93. 590 F.3d 866, 873 (D.C. Cir. 2010) (Al-Bihani argues that "the international laws of cobelligerency ... . demonstrate that the [fifty-fifth Arab Brigade] should have been allowed the opportunity to remain neutral upon notice of a conflict between the United States and the Taliban."). Similarly, D.C. Circuit and district courts adjudicated the claim that the law of war does not recognize material support as a triable offense. See Hamdan v. United States, 696 F.3d 1238, 1250 (D.C. Cir. 2012) ("[T]he issue here is whether material support for terrorism is an international-law war crime. The answer is no. . . There is no international-law proscription of material support for terrorism."); Hamlily v. Obama, 616 F. Supp. 2d 63, 76 (D.D.C. 2009) ("[d]etaining an individual who "substantially supports' ... an organization [engaged in hostilities against the U.S.], but is not part of it, is simply not authorized by the AUMF itself or by the law of war.").

94. Laird v. Tatum, 408 U.S. 1, 15-16 (1972).

95. Sosa v. Alvarez-Machain, 542 U.S. 692, 732 (2004).

96. 133 S. Ct. 1659, 1669 (2013). 
U.S. courts would not impose U.S. law on territory controlled by foreign sovereigns or interfere with foreign policy choices of the political branches. Recognizing a cause of action under section 1350 would reinforce the U.S. commitment to the rule of law, provide relief for clear violations of distinction or proportionality, and provide legal vindication for the drone program as a whole, both for the American public and our allies abroad.

Before delving into the legal arguments for why drone strikes in violation of the law of war satisfy the criteria set out in Sosa and Kiobel, it is worth recognizing that the facts of both cases lie at extreme ends of the spectrum of cases that might be brought under the ATS. The so-called "foreign cubed" fact pattern of Kiobel, which involved a foreign plaintiff, a foreign corporate defendant, and an alleged violation taking place wholly within the territory of a foreign sovereign, is significantly unlike drone strikes carried out by the U.S. military in territory that typically lacks foreign sovereign control. The facts of Sosa, whose ATS claim was also foreign cubed, involved an alleged illegal detention for a single day that was held not to constitute a clear violation of the law of nations. That is, the norm in question lacked the requisite international acceptance, and the violation was found to be both slight and remediable insofar as Alvarez-Machain was transferred to the custody of "lawful authorities" for "prompt arraignment" in less than twenty-four hours. ${ }^{98}$ By contrast, the facts of unlawful drone strikes involve permanent harm of the greatest magnitude, usually in the form of wrongful death, severe disabling injury, or extensive property damage. Moreover, insofar as the harm arises due to violations of distinction or proportionality, norms of an indisputably international character are invoked.

Violations of distinction and proportionality meet the high legal bar established in Sosa because they are universally accepted norms that place definite limits on military conduct. As the Sosa Court held, "courts should require any claim based on the present-day law of nations to rest on a norm of international character accepted by the civilized world and defined with a specificity comparable to the features of the eighteenth-century paradigms we have recognized." ${ }^{99}$ Distinction and proportionality are precisely norms of such specificity and international recognition. As noted above, they have been ratified as treaty obligations by 174 nations ${ }^{100}$ and recognized as binding customary international law by non-ratifying states, including the United States and Israel. ${ }^{101}$ As we have also seen, Air Force JAGs have an affirmative duty

97. See Oona Hathaway, Kiobel Commentary: The Door Remains Open to "Foreign Squared" Cases, SCOTUSBLoG (Apr. 18, 2013, 4:27 PM), http://www.scotusblog.com/2013/04/kiobel -commentary-the-door-remains-open-to-foreign-squared-cases.

98. Sosa, 542 U.S. at 738.

99. Id. at 725; see also Filartiga v. Pena-Irala, 630 F.2d 876, 888 (2d Cir. 1980) ("It is only where the nations of the world have demonstrated that the wrong is of mutual, and not merely several, concern, by means of express international accords, that a wrong generally recognized becomes an international law violation within the meaning of the statute.").

100. Additional Protocol I, supra note 12.

101. See, e.g., HCJ 769/02 Pub. Comm. Against Torture in Isr. v. Gov't of Isr. [2006](2) IsrLR 459 (Isr.); U.S. AIR FORCE, supra note 80 , at 88. 
to apply distinction and proportionality to every contemplated strike. ${ }^{102}$ Ex post judicial review of drone strikes would thus entail reviewing strikes for their compliance with these well-established universal norms. Courts should have an interest in adjudicating cases that appear to bring clear or egregious violations of these universal norms, such as reported strikes on wedding caravans or outdoor cafés where significant numbers of civilians have been killed. Statements by top U.S. officials ${ }^{103}$ and the military itself demonstrate that wanton disregard for the requirements of distinction and proportionality would constitute a universally recognized violation of the law of nations. ${ }^{104}$

In addition to the requirements of definite content and universal acceptance, the Kiobel court held that the ATS should be applied only where "claims touch and concern the territory of the United States . . . with sufficient force to displace the presumption against extraterritorial application." "105 All of the drone strikes in question do indeed take place on foreign soil. However, unlike the Kiobel defendant, Royal Dutch Petroleum, which had a "mere corporate presence" 106 in the United States, drone strikes are carried out solely by U.S. officials, who themselves derive their power from and are bound by U.S. law. ${ }^{107}$ Given direct U.S. military involvement, these cases fundamentally "touch and concern" the United States.

At least two early Opinions of the Attorney General buttress the view that harm committed against foreign nationals by U.S. citizens abroad sufficiently touches and concerns the United States. As the Sosa Court itself noted, in 1795, Attorney General William Bradford "was asked whether criminal prosecution was available against Americans who had taken part in the French plunder of a British slave colony in Sierra Leone."108 Although Bradford was uncertain about the availability of criminal prosecution, "he made it clear that a federal court was open for the prosecution of a tort action growing out of the episode." 109 Bradford argued that stated:

[T]here can be no doubt that the company or individuals who have been injured by these acts of hostility have a remedy by a civil suit in the courts of the United States; jurisdiction being expressly given to these courts in all cases where an alien sues for

102. U.S. AIR FORCE, supra note 80, at 95.

103. See, e.g., John O. Brennan, Ass't to the President for Homeland Sec. \& Counterterrorism, Remarks at the Woodrow Wilson International Center for Scholars in Washington, D.C.: The Ethics and Efficacy of the President's Counterterrorism Strategy (Apr. 30, 2012); Harold Hongju Koh, Legal Advisor, U.S. Dep't of State, Remarks at Annual Meeting of the American Society of International Law in Washington, D.C.: The Obama Administration and International Law (Mar. 25, 2010).

104. See In re Agent Orange Prod. Liab. Litig., 373 F. Supp. 2d 7, 137-38 (E.D.N.Y. 2005), aff'd sub nom. Vietnam Ass'n for Victims of Agent Orange v. Dow Chem. Co., 517 F.3d 104 (2d Cir. 2008); HCJ 769/02 Pub. Comm. Against Torture in Isr. v. Gov't of Isr. [2006](2) IsrLR 459 (Isr.); Legality of the Threat or Use of Nuclear Weapons, Advisory Opinion, 1996 I.C.J. 226 (July 8).

105. 133 S. Ct. 1659,1669 (2013).

106. Id.

107. See Reid v. Covert, 354 U.S. 1, 6 (1957) ("The United States is entirely a creature of the Constitution. Its power and authority have no other source. It can only act in accordance with all the limitations imposed by the Constitution.").

108. 542 U.S. 692, 721 (2004).

109. Id. 
a tort only, in violation of the laws of nations, or a treaty of the United States ... ${ }^{110}$

The Sosa Court went on to conclude, "[I]t appears likely that Bradford understood the ATS to provide jurisdiction over what must have amounted to common law causes of action." 111 A little more than a century later, Bradford's view was confirmed by one of his successors, Attorney General Charles J. Bonaparte. In 1907, when asked what legal remedies might be available for Mexican citizens harmed by the actions of an American irrigation company along the Rio Grande River, Bonaparte replied that the ATS "provide[s] a forum and a right of action." 12 Bonaparte added that the success of such suits should "be determined by judicial decision." "13 Bonaparte made explicit that courts should recognize a cause of action under the ATS when Americans violate "the principles of international law" and harm foreign nationals abroad. ${ }^{114}$ These opinions add further credibility to the position that torts in violation of substantive and universally accepted principles of international law sufficiently "touch and concern" the United States when they are committed by Americans abroad.

The Kiobel Court articulated two further concerns with the extraterritorial application of the ATS. The Court first explained that its "presumption [against extraterritorial application] 'serves to protect against unintended clashes between our laws and those of other nations which could result in international discord." "115 This concern that a clash of laws might sow international discord simply does not apply to drone strikes ${ }^{116}$ because strikes are governed by the international law of war that applies equally to the United States and other nations. Moreover, the geographic areas in which drone strikes are typically carried out are either war zones where sovereignty is in question or, more commonly, in zones where the local de jure sovereign does not maintain de facto control. ${ }^{117}$ These areas are more akin to the high seas and thus analogous to the pirate cases that were "beyond the territorial jurisdiction of the United States or any other country."118 The United States typically justifies drone strikes in Pakistan or Yemen as acts of self-defense carried out in territory

110. Id. (citing 1 Op. Att'y Gen. 59 (1795)).

111. Id. at 720. It is worth noting that the Sosa Court also cites two early foreign cubed cases in which ATS jurisdiction would have been recognized for an action for a tort only. Id. (citing Bolchos v. Darrel, 3 F. Cas. 810 (D.S.C. 1795) (No. 1,607); Moxon v. The Fanny, 17 F. Cas. 942 (D.Pa.1793) (No. $9,895)$ ).

112. Tel-Oren v. Libyan Arab Republic, 726 F.2d at 780 (Edwards, J., concurring) (citing 26 Op. Att'y Gen. 250, 252-53 (1907)).

113. Id.

114. Id.

115. Kiobel v. Royal Dutch Petroleum Co., 133 S. Ct. 1659, 1664 (2013) (citing EEOC v. Arabian Am. Oil Co. (Aramco), 499 U.S. 244, 248 (1991)).

116. The employment and securities regulation issues raised in the Aramco and National Australian Bank cases cited in Kiobel concern domestic, rather than international, law. See, e.g., Morrison v. Nat"l Austl. Bank Ltd., 561 U.S. 247, 269 (2010) ("Like the United States, foreign countries regulate their domestic securities exchanges and securities transactions occurring within their territorial jurisdiction. And the regulation of other countries often differs from ours as to what constitutes fraud, what disclosures must be made ....").

117. The Supreme Court specifically rejected the government's argument in Boumediene "that de jure sovereignty is the touchstone of habeas corpus jurisdiction." 553 U.S. 723, 755 (2008).

118. Kiobel, 133 S. Ct. at 1667. 
where the nominal sovereign is unable or unwilling "to suppress the threat." Because the de jure sovereign in the remote or "tribal" territories in question does not maintain de facto jurisdictional control, there is no sense in which recognizing a cause of action for Pakistani or Yemeni civilian plaintiffs harmed by drone strikes in clear violation of the law of war would be imposing "the sovereign will of the United States onto conduct occurring within the territorial jurisdiction of another sovereign." sovereign immunity, recognizing a cause of action in federal courts is the only hope for any form of relief for foreign civilians harmed by strikes in violation of the law of war.

In addition to worries about comity and international discord, the Kiobel court was concerned to avoid "impinging on the discretion of the Legislative and Executive Branches in managing foreign affairs." 121 The Court explained that " $[t]$ he presumption against extraterritorial application helps ensure that the Judiciary does not erroneously adopt an interpretation of U.S. law that carries foreign policy consequences not clearly intended by the political branches." While it is true that judicial decisions about law of war violations might carry foreign policy consequences by determining the legality or illegality of executive action abroad, the judiciary would be acting in a wholly appropriate role. Determining whether there has been wanton disregard for the limits that the United States itself recognizes as bearing on warfare is a quintessential legal task. In fact, as the Court explained in Sosa, the ATS provides "a judicial remedy" precisely for violations of the law of nations that "threaten[] serious consequences in international affairs." 123 In the case of drone strikes that egregiously violate the law of war, there is no risk of "adverse foreign policy consequences" that might follow "our courts ... sit[ting] in judgment of the conduct of foreign officials in their own countries with respect to their own citizens." 124 On the contrary, these cases entail only the indisputable function of the judiciary to pronounce on the legality or illegality of U.S. government action in an actual case or controversy.

Given the universal recognition of distinction and proportionality as definite limitations on war, the direct contact and concern of drone strikes for the U.S. territory, and lack of comity or foreign policy impropriety, courts should recognize a cause of action for aliens harmed by unlawful U.S. drone strikes abroad. Doing so would conform with the prevailing view, initially set out by Judge Edwards' analysis in Tel-Oren, that the ATS recognizes a cause of action where there has been a violation of a clearly defined law of nations. ${ }^{125}$ This understanding of the ATS was ratified in the Torture Victim Protection

119. DEP'T OF JUSTICE, LAWfulness OF A LETHAL OPERATION DiRECTED AGAINST A U.S. CitIZEN Who IS A SENIOR OPERATIONAL LEADER OF AL-QA'IDA OR AN ASSOCIATED FORCE 2 (2011).

120. Kiobel, 133 S. Ct. at 1667.

121. Id. at 1664 (quoting Sosa v. Alvarez-Machain, 542 U.S. 692, 727 (2004)),

122. $I d$.

123. Sosa, 542 U.S. at 715.

124. Id. at 728 (citing Tel-Oren v. Libyan Arab Republic, 726 F.2d at 813 (Bork, J., concurring)).

125. Tel-Oren, 726 F.2d at 780 (Edwards, J., concurring). 
Act (TVPA) of 1991 and its accompanying documents. The House Report on the TVPA explicitly states that section 1350 "should remain intact to permit suits based on other norms that already exist or may ripen in the future into the rules of customary international law." 126 As we have seen, the view expressed by the House also has a rich executive branch heritage dating back to Attorneys General Branford and Bonaparte. The overwhelming ratification of distinction and proportionality leaves no serious doubt that they are core elements of the law of nations. Given the universal recognition of the laws of distinction and proportionality, courts should find that their violation grants a cause of action to victims of unlawful drone strikes.

\section{Victims of Drone Strikes Have Standing}

Lack of standing has plagued some attempts to bring a case challenging governmental deprivations. As the Supreme Court recently stated in Clapper $v$. Amnesty International USA, "To establish Article III standing, an injury must be concrete, particularized, and actual or imminent; fairly traceable to the challenged action; and redressable by a favorable ruling." 27 The plaintiffs in Clapper and Al-Aulaqi were ultimately found to lack standing because they could prove neither that a harm had been committed nor the sufficient likelihood of a future harm. In contrast to these plaintiffs, victims of drone strikes have suffered a direct and demonstrable deprivation that can be directly traced to government action, and which can be redressed by a ruling that the deprivation was unlawful. As long as the case is brought by someone who has suffered a direct deprivation, courts should find that she satisfies the case or controversy requirement and thus has standing. ${ }^{128}$

\section{E. Declaratory Relief Circumvents Sovereign Immunity}

Having established jurisdiction, a cause of action, and standing, a plaintiff bringing suit as the victim of an unlawful drone strike will find sovereign immunity an almost insurmountable obstacle. As the Supreme Court stated in United States $v$. Sherwood, "It is elementary that the United States, as sovereign, is immune from suit save as it consents to be sued...., and the terms of its consent to be sued in any court define that court's jurisdiction to entertain the suit." 129 U.S. courts thus have no jurisdiction over cases brought against the United States in the absence of an explicit waiver of sovereign immunity. ${ }^{130}$ Although the Ninth Circuit found in Koohi that the case raised a

126. H.R. REP. NO. 102-367, as reprinted in 1992 U.S.C.C.A.N. 84, 86 (emphasis added).

127. Clapper v. Amnesty Int'l USA, 133 S. Ct. 1138, 1147 (2013) (internal quotations omitted).

128. Those bringing a wrongful death claim on behalf of the estate of deceased victims of unlawful strikes should also have standing. This view of standing is confirmed by the fact that the government did not raise, and Judge Collyer did not note, any standing issues with the estates of the victims bringing suit in Al-Aulagi II. See 35 F. Supp. 3d 56 (D.D.C. 2014).

129. 312 U.S. 584,586 (1941) (internal quotation marks omitted). Cf. United States v. Mitchell, 445 U.S. 535, 538 (1980) ("In the absence of clear congressional consent, then, there is no jurisdiction in the Court of Claims more than in any other court to entertain suits against the United States.' (internal quotation marks omitted)).

130. Cf. United States v. King, 395 U.S. 1, 4 (1969) ("A waiver of sovereign immunity cannot 
justiciable question, the court ultimately dismissed the case on the grounds that sovereign immunity prevented the government from being sued for damages. The court found that "the FTCA [Federal Tort Claims Act] contains an explicit exception for 'any claim arising out of combatant activities of the military or naval forces, or the Coast Guard, during time of war.",131 While Congress could amend the FTCA to remove the exception for military activities in war or pass legislation expressly waiving sovereign immunity for drone strikes carried out in clear violation of the law of war, ${ }^{132}$ damages relief is not available to victims of drone strikes at present.

The most common alternative to damages relief is the equitable relief of an injunction. As was recently demonstrated in Clapper, however, injunctive relief is plagued by the difficulty in presenting a convincing case that the harm in question is likely to be repeated in the future. For victims of drone strikes, particularly those who are deceased, there is virtually no hope of presenting the requisite likelihood of a repeated or future threat. ${ }^{133}$ Thus injunctive relief, like damages relief, will be unavailable to victims of unlawful drone strikes.

Thankfully Congress had the wisdom to provide a third alternative in the 1934 Declaratory Judgment Act. Now codified as 28 U.S.C. $\S 2201$, the Declaratory Judgment Act provides, "In a case of actual controversy within its jurisdiction, ... . any court of the United States . . . may declare the rights and other legal relations of any interested party seeking such declaration, whether or not further relief is or could be sought." 134 While the Supreme Court has emphasized that the Declaratory Judgment Act "created an opportunity, rather than a duty, to grant a new form of relief to qualifying litigants,", 135 it has also emphasized that courts have good reason to grant declaratory relief in cases that raise federal questions and for which there are no other remedies. ${ }^{136}$ Victims of allegedly illegal drone strikes present precisely such a case. Moreover, declaratory relief will serve a variety of legal and dignitary goals. A clarification of the legal status of victim's deaths will put their families or their estates in a position to know whether any further legal remedy may be available. The families or estates of victims, of drones strikes found to be carried out in violation of the law will also have the relief of knowing that their deaths were not justified or carried out legally. The very act of reviewing their deaths for their legality will show families that there is no right to treat their lives and deaths as unreviewable mistakes. The recognition and respect of formal legal proceedings and judgment will bring dignified closure to the

be implied but must be unequivocally expressed." (internal quotation marks omitted)).

131. Koohi v. United States, 976 F.2d 1328, 1333 (9th Cir. 1992).

132. A third possibility would be amending the Torture Victims Protection Act (TVPA) to include extra-judicial killing carried out by American officials. Presently, section 2(a) of the TVPA expressly limits liability to "[a]n individual who, under actual or apparent authority, or color of law, of any foreign nation." H.R. REP. No. 102-367, at 1 (1992) (emphasis added).

133. Clapper v. Amnesty Int'l USA, 133 S. Ct. 1138,1148 (2013).

134. 28 U.S.C. $\S 2201$ (a) (2012).

135. Wilton v. Seven Falls Co., 515 U.S. 277, 288 (1995); see also Pub. Serv. Comm'n of Utah v. Wycoff Co., Inc., 344 U.S. 237, 241 (1952) ("The Declaratory Judgment Act of 1934 ... is an enabling Act, which confers a discretion on the courts rather than an absolute right upon the litigant.").

136. Wilton, 515 U.S. at 290. 
victims' wrongful deaths.

From the perspective of those motivated to bring a case that actually reaches the merits, declaratory relief has the further virtue of enabling judgment against the U.S. government and military commanders by qualifying for a waiver of sovereign immunity. Section 702 of the Administrative Procedure Act (APA) provides:

A person suffering legal wrong because of agency action . . . is entitled to judicial review thereof. An action in a court of the United States seeking relief other than money damages . . . shall not be dismissed nor relief therein be denied on the ground that it is against the United States or that the United States is an indispensable party.

Section 702 opens the door to plaintiffs seeking declaratory judgment against military officials for alleged violations of the law of war because it does not involve "money damages." 138 Moreover, because drone strikes are ordered far from the field of battle, they are not subject to section $701(\mathrm{~b})(1)(\mathrm{G})$ of the APA, which excepts judicial review for "military authority exercised in the field in time of war or in occupied territory." 139 Courts should find strong reason to grant victims of drone strikes declaratory relief since, to paraphrase Justice Harlan's concurrence in Bivens, for victims of drone strikes, it is declaratory relief or nothing. ${ }^{140}$

\section{F. State Secrets Are Not Jeopardized by Judicial Review}

Assuming that plaintiffs clear the procedural and justiciability hurdles discussed thus far, they will most likely have to confront the final hurdle of the state secrets privilege. As the Supreme Court recognized over a century ago in Totten v. United States, "in exceptional circumstances courts must act in the interest of the country's national security to prevent disclosure of state secrets, even to the point of dismissing a case entirely." "Ind Indeed, in the recent $\mathrm{Al}$ Aulaqi v. Panetta case, the government argued that Aulaqi's complaint should be dismissed because "plaintiffs' allegations 'would inevitably require an inquiry into classified information that may undermine ongoing covert operations." "142 Thankfully Judge Collyer found this to be a losing claim,

137. 5 U.S.C. $\$ 702$ (2012) (emphasis added).

138. Indeed, the D.C. Circuit recognized in Sanchez-Espinoza v. Reagan that "ATS suits seeking non-monetary relief may proceed against the Secretary of Defense and the Director of the CIA under the APA's waiver of sovereign immunity." Al-Aulaqi I, 727 F. Supp. 2d 1, 41 (D.D.C. 2010) (describing Sanchez-Espinoza v. Reagan, 770 F.2d 202, 207 (D.C. Cir. 1985)).

139. 5 U.S.C. $\S 701(\mathrm{~b})(1)(\mathrm{G})(2012)$.

140. Speaking about desirability of a direct suit against the government for harm incurred by the action of government officials, Justice Harlan noted that "[h]owever desirable a direct remedy against the Government might be as a substitute for individual official liability, the sovereign still remains immune to suit. . . For people in Bivens' shoes, it is damages or nothing." Bivens v. Six Unknown Named Agents of Fed. Bureau of Narcotics, 403 U.S. 388, 410 (1971) (Harlan, J., concurring).

141. Mohamed v. Jeppesen Dataplan, Inc., 614 F.3d 1070, 1077 (9th Cir. 2010) (en banc) (citing Totten v. United States, 92 U.S. 105, 107 (1876)).

142. Defendants' Motion To Dismiss 12, Al-Aulaqi II, 35 F.Supp.3d 56 (D.D.C. 2014) (No. 1:12-cv-01192 (RMC)) (citing Wilson v. Libby, 535 F.3d 697 (D.C. Cir. 2008)). While the motion argues for dismissal on the basis of "special factors," it notes that "[t]he United States, which is not a 
ultimately rebuking the United States for its "truculent opposition" to her order to release classified information. ${ }^{143}$ Given the recent statements by Secretary of Homeland Security Jeh Johnson about our courts' ability to handle classified information, we should not expect invocations of the state secrets privilege to win much credibility with courts today.

In a discussion of possible drone courts, Johnson admitted that "Article III judges can receive highly sensitive classified information ex parte; in Washington, D.C., the infrastructure for doing this already exists."144 Indeed, in Boumediene, Judge Leon of the D.C. District Court ultimately ruled in favor of Boumediene's release at least in part on the basis of in camera review of the government's case against Boumediene. ${ }^{145}$ In fact, as Judge Graber of the Ninth Circuit has demonstrated, the infrastructure for dealing with classified information is not limited only to the D.C. courts. Judge Graber has herself recommended both in camera review and security clearances for defense attorneys. ${ }^{146}$ Many judges in and around the D.C. Circuit also require their law clerks to obtain security clearances in anticipation of handling classified information. Our federal courts' demonstrated ability to deal with classified information is yet another indication of their competence to review drone strikes, and do so without sacrificing state secrets or national security. Given our courts' ability to review classified information, the state secrets privilege should not prevent courts from reaching the merits of cases brought by victims of allegedly unlawful drone strikes.

The above discussion shows that courts can and should reach the merits of a case brought by a civilian victim seeking a declaration of the unlawfulness of the drone strike that injured him. Having looked at the issue solely from the side of how a victim might successfully bring a case, I can now add that the government also has a real interest in such cases reaching the merits. Apart from the relief granted to individual victims of strikes, declaratory judgment will have the further effect of either vindicating the lawfulness and legitimacy of U.S. drone strikes where they are found to be legal, or compelling internal reform where specific strikes are found to be carried out unlawfully. If the President and military are truly interested in convincing the American people and our allies of the legality and legitimacy of the drone program, they should want to demonstrate the lawfulness of specific strikes that harm civilians in federal court. A failure to vindicate the drone program in court will lead to greater U.S. isolation and thus greater insecurity. ${ }^{147}$ Given the value of

party to this suit, has filed a statement of interest and has reserved its right to invoke the state secrets privilege in the event this case proceeds beyond the motion-to-dismiss stage." Id. at 15-16. The motion also argues that Aulaqi's complaint should be dismissed because it raises non-justiciable political questions. Id. at 27.

143. Al-Aulaqi II, 35 F. Supp. $3 \mathrm{~d}$ at 81 .

144. Johnson, supra note 4.

145. Boumediene v. Bush, 579 F. Supp. 2d 191, 197 (D.D.C. 2008), rev'd sub nom. Bensayah v. Obama, 610 F.3d 718 (D.C. Cir. 2010). 2012).

146. Al Haramain Islamic Found., Inc. v. U.S. Dep't of Treas., 686 F.3d 965, 982-84 (9th Cir.

147. See Somaiya, supra note 31 ; Stark, supra note 31. 
intelligence cooperation in counter-terrorism, demonstrating the lawfulness of drone strikes should be a national security priority.

\section{Due Process of War In Practice}

Given that I have argued throughout for ex post judicial review of drone strikes, it is reasonable to expect some illustration of just how courts can review strikes for their compliance with distinction and proportionality. ${ }^{148}$ Before looking at an actual example, we should familiarize ourselves with the ground rules. First, in assessing compliance with distinction and proportionality, courts are assessing the legal evaluation of commanders for their reasonableness. ${ }^{149}$ Courts should thus focus their review on the legal analysis and recommendation given by JAGs and adopted by commanders, particularly where commanders overrule JAG legal assessments. Given the pre-planned nature of drone strikes and the relative calm and security from which they are carried out, judges can anticipate a relatively robust JAG legal analysis for their review.

As for specific judicial tests, courts should look to the basic principles of distinction and proportionality as defined in the law of war. Most fundamentally, distinction requires that "[p]arties to the conflict shall at all times distinguish between the civilian population and combatants and between civilian objects and military objectives and accordingly shall direct their operations only against military objectives." 150 With respect to persons targeted, the law of distinction expressly exempts civilians from attack and the "dangers arising from military operations." 151 Distinction defines civilian objects negatively as all those objects that are not military. ${ }^{152}$ In turn, military objects are defined as "those objects which by their nature, location, purpose or use make an effective contribution to military action and whose total or partial

148. While a comprehensive discussion of the law of war bearing on drone strikes is beyond the scope of this article, the proper approach to military advantage and proportionality in the targeted killing context is described in Joshua Andresen, New Voices, Challenging the Perplexity over Jus in Bello Proportionality, 7 EUR. J. LEGAL STUD. 19(2014).

149. See Prosecutor v. Galić, Case No. IT-98-29-T, Judgement and Opinion, ๆ 58 (Int'l Crim. Trib. for the Former Yugoslavia Dec. 5, 2003).

150. Additional Protocol I, supra note 12, art. 48; see also id. arts. 44(3) ("In order to promote the protection of the civilian population from the effects of hostilities, combatants are obliged to distinguish themselves from the civilian population while they are engaged in an attack or in a military operation preparatory to an attack."), 51(3) ("Civilians shall enjoy the protection afforded by this Section, unless and for such time as they take a direct part in hostilities."), 52(2) ("Attacks shall be limited strictly to military objectives. In so far as objects are concerned, military objectives are limited to those objects which by their nature, location, purpose or use make an effective contribution to military action and whose total or partial destruction, capture or neutralization, in the circumstances ruling at the time, offers a definite military advantage."), 57(3) ("When a choice is possible between several military objectives for obtaining a similar military advantage, the objective to be selected shall be that the attack on which may be expected to cause the least danger to civilian lives and to civilian objects.").

151. Id. art. 51(1). The only exception is that civilians may be targeted "for such time as they take a direct part in hostilities." Id. art. 51(3). Since the drone strikes in question are pre-planned attacks on known militants and generally carried out away from hot battlefields, we can expect that the exception for targeting civilians taking a direct part in hostilities will rarely be invoked.

152. Id. art. 52(1) ("Civilian objects shall not be the object of attack or of reprisals. Civilian objects are all objects which are not military objectives as defined in paragraph 2 [of Article 52 in the Additional Protocol I]."). 
destruction, capture or neutralization, in the circumstances ruling at the time, offers a definite military advantage." 153 As we know, drone strikes are frequently carried out against targets that strain a strict civilian-military object distinction. The law of distinction anticipates the problem posed by "dual-use" objects that have both a civilian and a military function and counsels that "[i]n case of doubt whether an object which is normally dedicated to civilian purposes, such as a place of worship, a house or other dwelling or a school, is being used to make an effective contribution to military action, it shall be presumed not to be so used." 154 In the typical drone strike against an enemy combatant, the combatant himself will be a lawful target. The lawfulness of targeting the enemy combatant may, however, be negated if, in order to target the combatant, a civilian object, such as a wedding caravan or an outdoor café that is not making any effective contribution to military action, is targeted for the drone strike. In other words, distinction requires a functional analysis of the target object in question. Where part of a radio station, for example, has been taken over as a militant command center, it would qualify as a proper military object and satisfy distinction. Where, however, a single militant happens to be present at a hospital, school, market, café, or apartment building that continues to function in its ordinary civilian capacity and serve its normal civilian function, the object retains its civilian character and should not be targeted.

In addition to the rules of distinction, courts should review a strike's compliance with proportionality. The rule of proportionality in attack becomes applicable whenever the legitimate targeting of a military person or object can be expected to cause harm to civilians or civilian property. In such cases, proportionality prohibits attacks "which may be expected to cause incidental loss of civilian life, injury to civilians, damage to civilian objects, or a combination thereof, which would be excessive in relation to the concrete and direct military advantage anticipated." 155 Proportionality applies only to the anticipated harm and anticipated military advantage, and holds commanders to a reasonable assessment of these criteria. ${ }^{156}$ If we assume that drone strikes are carried out in self-defense to avert terrorist attacks and save American civilian and soldier lives, then the military advantage of the strike will involve a reasonable assessment of the magnitude of the threat posed by the intended target and the advantage of eliminating it. ${ }^{157}$ The magnitude of the threat can then be compared with the harm anticipated to accrue to civilians and civilian objects as a result of the proposed strike. Here the test is a balancing one where strikes will fail when harm to civilians and civilian objects is excessive in

153. Id. art. 52(2).

154. Id. art. $52(3)$

155. Id. arts. 51(4), 51(5)(b); see also Rome Statute, supra note 81, art. 8(2)(b)(iv); Additional Protocol I, supra note 12, arts. 57(2)(a)(ii), 57(2)(b).

156. On the importance of focusing on anticipated rather than actual results, see Michael Schmitt, Military Necessity and Humanity in International Humanitarian Law: Preserving the Delicate Balance, 50 VA. J. INT'L L. 795, 825 (2010) ("[T]he legal question is the relationship between expected harm and anticipated advantage in the operation as planned, not that which eventuated.").

157. For a more detailed argument that military advantage must be adjusted for likelihood of success and uniqueness of opportunity see Andresen, supra note 148, at 31-32. 
relation to the anticipated military advantage. There will be easy cases at both ends of the spectrum. Clearly passing cases will be those where anticipated military advantage is great and anticipated harm very small. Clearly failing cases will be those where anticipated military advantage is small or negligible and anticipated harm significant. As for the "close calls" in the middle, courts and judges should be heartened by three realizations: (1) that JAGs make these calls every day and courts will be able to follow and review their legal analyses; (2) that the test is for excessiveness, which means close cases tip in favor of the reasonable commander; and (3) that proportionality tests are common in a wide variety of civil litigation today. As the Eastern District of New York recently found in the Agent Orange case, "American courts are fully capable of applying the proportionality concept in civil litigations as demonstrated by their handling of comparative negligence, proximate cause and other sophisticated doctrines." 158

Given an overview of the rules and principles governing distinction and proportionality, we can now examine a concrete case. Returning to the first scenario sketched at the beginning of this Note, we can illustrate how it holds up against judicial review. In that scenario, a wedding party traveling along a remote road in the high desert of Yemen is struck by drones, killing twelve civilians and five suspected militants. ${ }^{159}$ Before we can assess whether this strike reasonably complied with distinction and proportionality we must know what the military commander-in-charge anticipated. Let us start with a relatively easy scenario. If the commander reasonably believed, for example, on the basis of an intelligence source that had proven reliable in the past, that the wedding caravan was in fact a military convoy containing only enemy combatants, then he would have fired at what he took to be a legitimate military object with little or no anticipated civilian harm. In such a scenario, despite what may be a terribly unfortunate result, the commander would have complied completely with distinction and proportionality.

Moving to a more difficult, and perhaps more realistic, scenario, let us imagine that the commander anticipated the events more or less as they occurred. The commander received reliable intelligence that five enemy militants would be traveling as part of a wedding party between two villages in a remote area of Yemen. The militants were not attempting to disguise or smuggle themselves. They were, in fact, taking part in the wedding procession alongside family and friends. Although the wedding procession was composed of at least fifty civilians, the commander had reliable intelligence that the procession presented a rare opportunity to target the militants and that they would be located in the last three vehicles in the procession, which would

158. In re Agent Orange Prod. Liab. Litig., 373 F. Supp. 2d 7, 137-38 (E.D.N.Y. 2005), aff'd sub nom. Vietnam Ass'n for Victims of Agent Orange v. Dow Chem. Co., 517 F.3d 104 (2d Cir. 2008). Although the Eastern District of New York declined to recognize a cause of action for the United States's allegedly excessive use of the "Agent Orange" herbicide in Vietnam more than forty years earlier, the easily distinguishable facts of drone strikes present much more straightforward cases for application of distinction and proportionality by our federal courts today.

159. For the purpose of this discussion, I am assuming that all jus ad bellum requirements are met and will focus solely on jus in bello distinction and proportionality. 
contain approximately twelve civilians in addition to the militants. Although the commander believed the intelligence was reliable, he was experienced enough to know that these militants often change their plans or leak bad intelligence to hinder detection of their location. Adjusting for the probable accuracy of the intelligence, the commander concludes that if he targets the final three vehicles of the procession, he can reasonably anticipate killing two or three of the militants and somewhere between twelve and twenty civilians. Erring on the side of caution, he anticipates killing two militants and twenty civilians. He gives this information to his JAG and asks, can I order the strike?

The JAG immediately runs up against a challenging distinction analysis. The militants are clear lawful targets. However, the wedding procession is a clear civilian object that does not appear to be "used to make an effective contribution to military action." in the procession in order to carry out an attack, it might be a different story. However, on the information known, there is no credible claim that the wedding procession was being used for a military purpose. The JAG thus concludes that the strike would violate distinction. While that is enough to answer his commander in the negative, he knows that the commander will want an analysis of proportionality as well. The JAG knows that these militants have confirmed involvement in planned attacks that would have killed hundreds of civilians if they were not thwarted at the last second. He also knows that the militants are continuing to plan and order attacks that have the potential to kill hundreds of civilians in the future. Reasoning that if the militants are not stopped they will eventually succeed in one of their plots and kill hundreds of civilians, the JAG concludes that even if twenty civilians are killed and only two militants are killed, ${ }^{161}$ the military advantage still exceeds the anticipated harm by a significant margin. He thus reports to his commanding officer that he should not order the strike because, even though the strike would be proportionate, distinction prohibits the strike. The wedding procession is a civilian object not making any "effective contribution to military action."

The commander does not like this answer. He believes the procession is making an effective contribution to military action by shielding the militants from what would otherwise be a lawful strike. He believes that enemy militants should not be able to take advantage of "human shields." The JAG is sympathetic with the commander's frustration, but reminds him that this is simply not a lawful target and, anyway, we do not want to set an example for strikes that we would be loath to see others replicate. The commander ultimately overrules the JAG, believing he can rationalize the wedding caravan as a military object making an effective contribution to military action, and orders the strike.

160. Additional Protocol I, supra note 12, art. 52(3).

161. A more sophisticated proportionality analysis would also take into account the deleterious effects on military advantage of killing civilians if, for example, the death of civilians can be expected to lead to the recruitment of many more enemy militants. As the Counterinsurgency Field Manual insightfully notes, some actions that "provide a short-term military advantage" may actually "help the enemy." DEP'T OF THE ARMY, FM 3-24/MCWP 3-33.5, COUNTERINSURGENCY app. A, at A-5 (2006). 
This is an admittedly challenging case to review. The court will ultimately have to determine whether the wedding procession was a lawful target, whether the commander acted lawfully, and whether to credit the JAG's analysis. However, making these determinations is no more challenging than determining whether the government has established that a detainee was, in fact, an enemy combatant on the basis of classified evidence ${ }^{162}$ or whether Combatant Status Review Tribunals satisfy the requirements of due process. ${ }^{163}$ We should bear in mind that judicial review of drone strikes does not require judges to second guess conventional war decisions in hot battlefields. Drone strikes do not take place in the fog of war where soldiers risking their lives must make life and death decisions in a split second. Precisely because drone strikes occur in contexts with no threat to U.S. service personnel, they transpire and can be reviewed on much more objective grounds. Courts would review commanders' actions in the safety and calm of a drone command center, specifically for their compliance with the legal requirements of identifying and distinguishing military from civilian objectives and weighing the expected civilian casualties against the expected military advantage. Given our courts' demonstrated competency and our national and military commitment to the laws of war, it is time for the courts to meet the challenge of reviewing the legality of drone strikes that appear to violate distinction or proportionality.

\section{CONCLUSION}

I have argued that ex post judicial review of drone strikes would make us both more secure and more faithful to our core constitutional commitments. The constitutional demand for judicial review of military force is the most serious check on the executive in a democratic society of law. Vindicating the lawfulness and legitimacy of drone strikes is crucial to our future security given our permanent counter-terrorism footing. Our allies are already demanding legal assurances in exchange for intelligence cooperation and we should demand judicial review to restore our constitutional balance of powers.

Despite the challenges inherent in accurately and proportionately targeting enemy militants with drones, drone strikes have the potential to be paradigm cases of compliance with the laws of war. Drone strikes are purportedly among the most thoroughly researched, contemplated, and reviewed decisions in the history of warfare. Given the military's own application of the laws of distinction and proportionality to targeting, retrospectively reviewing whether the commanding officers reasonably complied with these legal demands should be a judicial task wholly within the competence of our courts.

Given the feasibility of ex post judicial review and its security and constitutional advantages, the executive, the military, and our courts should all support ex post judicial review drone strikes. Even a case that merely passes the

162. Boumediene v. Bush, 579 F. Supp. 2d 191, 196 (D.D.C. 2008), rev'd sub nom. Bensayah v. Obama, 610 F.3d 718 (D.C. Cir. 2010).

163. Boumediene v. Bush, 553 U.S. 723, 785 (2008). 
pleading stage will have a tremendous effect on reinforcing the rule of law and vindicating the program. Reassuring our allies abroad of the legality of the program will have immediate national security benefits through enhanced intelligence sharing. Reassuring congressional critics and the American people of the legality of the program will help restore our constitutional balance of powers and democratic legitimacy for the most serious action that government can take in our name. With no end to counterterrorism operations in sight and the military turning overwhelmingly to unmanned aircraft, the lawfulness and legitimacy of the drone program is essential to an effective national security strategy going forward. 